\title{
Expressions of hepatic genes, especially IGF-binding protein-1, correlating with serum corticosterone in microarray analysis
}

\author{
R Y S Cheng, L A Birely ${ }^{1}$, N L Lum ${ }^{1}$, C M Perella ${ }^{1}$, J M Cherry ${ }^{1}$, N K Bhat ${ }^{1}$, \\ K S Kasprzak, D A Powell ${ }^{2}$, W G Alvord ${ }^{2}$ and L M Anderson \\ Laboratory of Comparative Carcinogenesis, National Cancer Institute at Frederick, Building 538, Ft Detrick, Frederick, Maryland 21701, USA \\ ${ }^{1}$ SAIC-Frederick, Inc., Frederick, Maryland, USA \\ ${ }^{2}$ Data Management Services, Inc., Frederick, Maryland, USA
}

(Requests for offprints should be addressed to R Y S Cheng; Email: rcheng@mail.ncifcrf.gov)

\begin{abstract}
Microarray technology was evaluated for usefulness in assessing relationships between serum corticosterone and hepatic gene expression. Nine pairs of female Swiss mice were chosen to provide a wide range of serum corticosterone ratios; cDNA microarray analysis ( 8000 genes) was performed on their livers. A statistical method based on calculation of $99 \%$ confidence intervals discovered 32 genes which varied significantly among the livers. Five of these ratios correlated significantly with serum corticosterone ratio, including tyrosine aminotransferase, stress-induced protein, pleiotropic regulator 1 and insulin-like growth factor-binding protein-1; the latter has a potential role in cancer development. Secondly, linear regression of gene expression vs corticosterone ratios was screened for those with $r \geq 0.8(P<0.01)$, yielding 141 genes, including some known to be corticosterone regulated and others of interest as possible glucocorticoid targets. Half of these significant correlations involved data sets where no microarray ratio exceeded \pm 1.5 . These results showed that microarray may be used to survey tissues for changes in gene expression related to serum hormones, and that even small changes in expression can be of statistical significance in a study with adequate numbers of replicate samples.
\end{abstract}

Journal of Molecular Endocrinology (2004) 32, 257-278

\section{Introduction}

Glucocorticoids are well known to regulate the expression of numerous genes in liver for control of energy metabolism, in response to stress, and as part of other physiological processes. In the past, these regulatory events have been revealed by experimental manipulation in vivo through ablation or hormonal supplementation studies, and by hormone treatment of hepatic cells in culture. In general, such investigations have involved large changes in hormone levels and hence pertain particularly to gene responses under extreme conditions. Fewer studies have been carried out to find changes in gene expression that occur in liver during the hourly fluctuations in circulating glucocorticoids that accompany diurnal rhythms, varying physical activity levels, and feeding. Also, there have been no comprehensive assessments of the total number and nature of the hepatic genes that may be influenced by glucocorticoids.

As a first step in gathering information on these topics, we have undertaken microarray analysis of normal mouse liver genes with a set of approximately $8000 \mathrm{cDNAs}$, and have correlated gene expression ratios with ratios of levels of serum corticosterone. Mice were analyzed in pairs, chosen on the basis of differing serum corticosterone; microarray analysis of gene expression was carried out for each liver. The ratio of serum corticosterone for the pair was then matched with the ratio of expression of each hepatic gene for that pair, for xy plotting of corticosterone ratio vs hepatic gene expression ratio. With nine pairs of livers, we found significant $(P<0 \cdot 01)$ correlations between serum corticosterone and microarray ratios for 141 genes. 
Some of these genes are known to be glucocorticoid responsive, while others are revealed as potential glucocorticoid targets for the first time. Of particular interest was insulin-like growth factor-binding protein-1 (Igfbp1), which, of all the genes correlated with serum corticosterone, showed the widest range of expression ratios. This protein plays a key role in regulating the actions of insulin-like growth factors (IGF)-I and -II, important contributors to growth control and cancer development (Wetterau et al. 1999). The results with Igfbpl were confirmed by both reverse transcription (RT)-PCR and real-time PGR. These studies have established, for the first time, the utility of microarray for relating serum parameters to gene expression in organs and establish a possible mechanism by which altered serum corticosterone could influence neoplasia development in multiple tissues.

\section{Materials and methods}

\section{Animals and corticosterone analyses}

Animals were maintained and handled in a facility fully accredited by the American Association for the Accreditation of Laboratory Animal Care, in accordance with the policies established by that organization and by National Institutes of Health (NIH) guidelines (Guide for the Care and Use of Laboratory Animals, NIH Publication No. 86-23 1985). Female Swiss Cr:NIH(S) mice were bred from parents obtained from the Animal Production Area at the National Cancer Institute at Frederick. They were maintained on hardwood shavings as bedding, given NIH open formula autoclavable mouse chow (PMI, Inc., Richmond, IN, USA) and acidified water, under conditions of $72 \pm 7^{\circ} \mathrm{C}$, $50 \pm 20 \%$ humidity, and a fluorescent light cycle of $12 \mathrm{~h}$ light: $12 \mathrm{~h}$ darkness. The mice were killed by decapitation between 0930 and $1200 \mathrm{~h}$. Preliminary studies showed that stress-related changes in serum corticosterone could be reduced by acclimatizing the mice to the laboratory and to brief handling before they were killed (not shown). Sera and livers were immediately frozen in liquid nitrogen and stored at $-70{ }^{\circ} \mathrm{C}$ until use. Total serum corticosterone was assayed by AniLytics, Inc. (Gaithersburg, MD, USA), utilizing a ${ }^{125} \mathrm{I}$ radioimmunoassay kit from ICN Biomedicals, Inc. (Irvine, GA, USA).
Liver samples were chosen so as to represent mice with a range of serum corticosterone values. In experiment 1 , these values ranged from 25 to $740 \mathrm{ng} / \mathrm{ml}$. Pairs for microarray analysis were selected so as to construct a wide range of serum corticosterone ratios, including eight that were uniformly distributed plus a lower extreme of $0 \cdot 034$ (pair 9 in Table 1). For the second confirmatory experiment assayed with real-time PCR, sera and livers were from an independent group of female mice of the same strain.

\section{Microarray analysis}

Total RNA was extracted from a sample of each liver by homogenization in the presence of Trizol (Life Technologies, Inc.). mRNA was isolated with oligo dT (Oligotex; Qiagen Co., Valencia, CA, USA). One microgram mRNA of each sample was submitted to Incyte Genomics, Inc. (Fremont, CA, USA) for the RT, microarray hybridization, and quantification process. ScanArray (Perkin Elmer Co., Wellsley, MA, USA) and GenePix Software (Union City, CA, USA) were used to acquire microarray image analysis and for quantification. Both endogenous and exogenous internal controls were included to monitor the quality and quantity of each array. Further information regarding Incyte Genomics may be found on the web site (www.incyte.com). Identifications of the Integrated Molecular Analysis of Genes and their Expression (I.M.A.G.E.) clones, used for preparation of the Incyte Genomics chips, were by reference of chip identification numbers to GenBank and dbEST, as of 15 April 2003. The reader is advised that definitive identification of some I.M.A.G.E. clones is still an evolving process.

Microarray data were downloaded from Incyte Genomics with a file transfer protocol to a Microsoft Windows NT 4.0 workstation equipped with GEMTools, a proprietary microarray analysis software from Incyte Genomics. Tab-delimited format microarray data files and pseudocolor plate-view PDF files were also downloaded from the company website. The data were prefiltered such that spots that were not at least $40 \%$ covered or that had a signal/background ratio less than $2 \cdot 5$ were omitted. Tab-delimited data files were imported to Microsoft Excel $97 / 2000$ and to various mathematical and statistical packages for analysis. 
The distribution of the data for each microarray pair was evaluated by the method of Chen et al. (1997). Briefly, this method requires the calculation of a maximum likelihood estimate for the common coefficient of variation of the entire cDNA set. This method is used to specify the probability density function for the ratio of the set. Knowledge of this, in turn, enables one to calculate the lower and upper limits of a confidence interval (CI) for the array (Chen et al. 1997, Powell et al. 2002). As noted previously, by chance alone, only one cDNA of the $\sim 8000$ assessed is expected to be found outside of the $99 \%$ CI in two array sets. It is highly unlikely that any given cDNA will occur outside of the 99\% CI of three or more array sets. This strategy enabled us to identify genes whose apparent changes in expression were not due to chance alone.

As an additional analytical strategy, correlations of microarray ratios were sought with serum corticosterone ratios and with the logs of these ratios. In addition, corticosterone ratios less than one were converted to negative reciprocals, to parallel the representation of downregulated genes as negative values in the microarray. This format is referred to in this report as a reciprocal ratio. All three presentations of the corticosterone ratio data were tested for significant correlation with the expression of each of the $\sim 8000$ genes in nine arrays. All genes with a correlation value of $r=0 \cdot 80$ or better for any of the three corticosterone ratio data sets were selected. This corresponded to a significance of $P=0.01$ or better. There were 141 genes that met this criterion. Each of these genes was then examined separately for significance of the correlations by linear regression analysis. Each correlation was also tested for significance when the lower extreme value was omitted.

\section{RT-PCR for Igfbp1}

Specific IGF-binding protein-1 (Igfbp-1) primers (forward: ctctgcatgccetcacc and reverse: ccagcagctg ttcctct) were designed with Primer3 (www.genome. wi.mit.edu). The 18s RNA, amplified in parallel, served as an internal and amplification control. Synthesis of the first strand of cDNA was performed by the use of RETROScript (Ambion Corp.). A $20 \mu \mathrm{l}$ reaction mixture, containing $2 \mu \mathrm{g}$ total RNA, $100 \mathrm{U}$ M-MLV RT, $1.25 \mu \mathrm{M}$ random hexamers, $10 \mathrm{U}$ placental RNase inhibitor, $0.5 \mathrm{mM}$
dNTPs, $1.5 \mathrm{mM} \mathrm{MgCl}_{2}, 50 \mathrm{mM} \mathrm{KCl}$, and $10 \mathrm{mM}$ Tris- $\mathrm{HCl}, \mathrm{pH} 8 \cdot 3$, was incubated at $42{ }^{\circ} \mathrm{C}$ for $1 \mathrm{~h}$ and then heated to $92{ }^{\circ} \mathrm{C}$ for $10 \mathrm{~min}$ to denature the RT. An aliquot of $2 \mu \mathrm{l}$ cDNA mixture was then amplified for the Igfbp and Classic $18 S$ RNA internal amplification control (Ambion QuantumRNA 18s RNA). The amplification reaction mixture consisted of $0 \cdot 125 \mathrm{mM}$ Tris- $\mathrm{HCl}, \mathrm{pH} 8 \cdot 3$, $50 \mathrm{mM} \mathrm{KCl}, 1.5 \mathrm{mM} \mathrm{MgCl}{ }_{2}, 5 \mu \mathrm{M}$ each forward and reverse primers, and $2 \cdot 5 \mathrm{U}$ Taq DNA polymerase (Ambion SuperTaq Plus) in a final volume of $50 \mu \mathrm{l}$. An RT-free reaction was run as a negative control. Optimum linearity conditions for the multiplex RT-PCR amplification along with 18s RNA were established $\left(57^{\circ} \mathrm{C}, 25\right.$ cycles). PCR products were electrophoresed through a $10 \%$ polyacrylamide gel in Tris-borate-EDTA buffer. Bands were quantified with Sybr Green II (Molecular Probes, Inc., Eugene, OR, USA) and luminescence was measured in a digital image system (Alpha Innotech, IS-1000, San Leandro, CA, USA). The intensity of each band was normalized to the intensity of the corresponding 18s RNA control bands.

\section{Real-time PCR for Igfbp1}

Specific primers for real-time PGR quantification of Igfbpl mRNA were designed using Primer Express software (Applied Biosystems, Forster City, CA, USA) and optimized for amplification and minimal primer dimer formation. Accurate quantification of $I g f b p 1$ mRNA was achieved using a plasmid vector containing the mouse $I g f b p 1 \mathrm{cDNA}$ obtained from the American Type Culture Collection (Manassas, VA, USA; I.M.A.G.E. no. 4161889). DNA sequencing from both the $5^{\prime}$ and $3^{\prime}$ ends verified identity. The real-time PCR assays for Igfbpl plasmid DNA or cDNA were carried out in $20 \mu \mathrm{l}$ reactions using primers (forward primer CTC TGG ATG CGC TGACG; reverse primer CGA GCA GCT GTT CCT CT) and SYBR Green master mix (Qiagen Inc.) and run on an ABI 8900 (Applied Biosystems, Inc., Foster City, CA, USA) for 40 cycles $\left(95{ }^{\circ} \mathrm{C}\right.$ for $15 \mathrm{~min}$, $95^{\circ} \mathrm{C}$ for $15 \mathrm{~s}, 60{ }^{\circ} \mathrm{C}$ for $30 \mathrm{~s}$; then a dissociation curve: $95{ }^{\circ} \mathrm{C}$ for $15 \mathrm{~s}, 60{ }^{\circ} \mathrm{C}$ for $15 \mathrm{~s}$ and then a $2 \%$ ramp rate to $95^{\circ} \mathrm{C}$ for $15 \mathrm{~s}$ ). The standard, mouse glyceraldehyde-3-phosphate dehydrogenase (Gapdh) plasmid DNA was purchased from Serologicals (Gaithersburg, MD, USA). The real-time PCR 
Table 1 Pairs of female mouse serum and liver utilized

\section{Serum corticosterone}

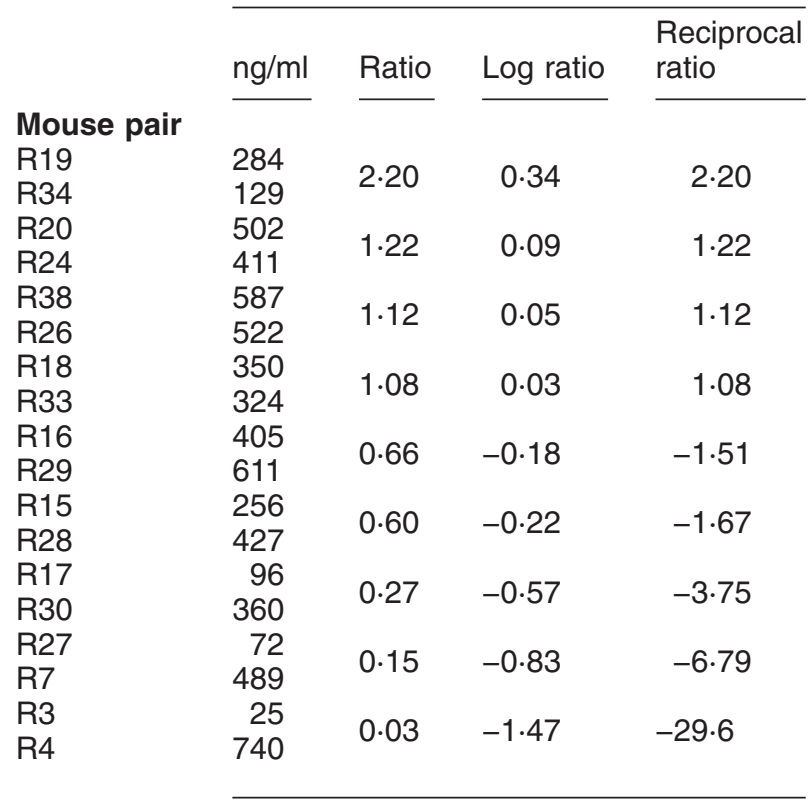

assays for Gapdh plasmid DNA was carried out in $20 \mu \mathrm{l}$ reactions using the mouse GAPDH control kit (Applied Biosystems) and run on an ABI 7900 for 40 cycles $\left(95^{\circ} \mathrm{C}\right.$ for $15 \mathrm{~min}, 95^{\circ} \mathrm{C}$ for $15 \mathrm{~s}, 60{ }^{\circ} \mathrm{C}$ for $30 \mathrm{~s}$, then a dissociation curve: $95^{\circ} \mathrm{C}$ for $15 \mathrm{~s}$, $60{ }^{\circ} \mathrm{C}$ for $15 \mathrm{~s}$ and then a $2 \%$ ramp rate to $95^{\circ} \mathrm{C}$ for $15 \mathrm{~s}$. Sensitivity and linear dynamic range were checked on the serial dilutions $\left(10\right.$ to $10^{6}$ copies/reaction) of Igfbp1 and Gapdh plasmid DNA and found to be $>98 \%$ efficient with a slope of $3 \cdot 6$. The $\lg f b p 1 \mathrm{mRNA}$ expression was normalized to the Gapdh expression in multiplex and quantified with its own standard curve, $>97 \%$ efficiency with a slope of $-3 \cdot 8$.

\section{Results}

\section{Genes with significant among-pairs variation}

The features of the nine pairs of mice used are given in Table 1, including the absolute concentration of corticosterone in the serum and the serum corticosterone ratios for each pair. The last pair listed, with a corticosterone ratio of 0.03 , is referred to as the 'lower extreme value' in the analyses which follow.
cDNA at 35 locations on the microarray chips showed a significant range in values among pairs, after application of the winnowing procedure based on the 99\% confidence limits (see Materials and methods). Of these, 23 represented known genes. Two were present at two or more chip locations, providing confirmation of the results. Thus, expressions of 21 known genes showed significant variability among these normal livers, by this conservative statistical procedure.

Since the liver pairs had been selected on the basis of serum corticosterone, we next tested each of the 35 array ratios for significance of correlation with serum corticosterone ratios. Six were significant at $P<0 \cdot 05$ : one EST, one hypothetical protein, and Igfbp1, stress-induced protein, pleiotropic regulator 1, and tyrosine aminotransferase (Table 2). Microarray ratios for all of these genes were positively associated with serum corticosterone ratios, except for pleiotropic regulator 1, for which the correlation was negative.

Genes which showed significant expression variation among livers, but did not correlate with serum corticosterone, included metallothionein 1, lipin 1, presenilin 2, cytochrome P450 4a14, cytochrome P450 4a10, fatty acid synthase, aquaporin 1, macrophage activation protein 2, $\mathcal{N}$-methyl-D-aspartate receptor-regulated gene 1, chloride intracellular channel 1 (mitochondrial), deleted in azoospermia-like, glutamate oxaloacetate transaminase 1, pancreatic colipase, aminolevulinic acid synthase 1, long chain fatty acyl elongase, and enolase 1, alpha non-neuron. Many of these showed wide ranges in array ratios among the nine liver pairs, from -5 to $+5 \cdot 8$.

\section{Gene expression ratios correlating with serum corticosterone}

Additional correlations of gene expression with serum glucocorticoid were sought by linear regression analysis and selection of cDNAs with $r \geq 0.8$ for the nine pairs, as related to corticosterone ratio, log of this ratio, or reciprocal ratios (see Materials and methods). A total of 141 genes met this criterion (Table 3); of these, 112 correlated positively with serum corticosterone, and 29 correlated negatively. Ratios of 83 genes, listed in Table 4, maintained their significant correlation with corticosterone ratio when the lower extreme value was omitted; thus these showed correlation over a wide range of corticosterone values and 
Table 2 Genes showing significant expression variation among the nine pairs of livers, based on $\mathrm{Cl}$ calculations, and also significant correlation with serum corticosterone ratios

\begin{tabular}{|c|c|c|c|c|}
\hline & Clone name & $\begin{array}{l}\text { I.M.A.G.E. } \\
\text { clone } \\
\text { identification }\end{array}$ & $\begin{array}{l}\text { Range of } \\
\text { microarray } \\
\text { values }\end{array}$ & $\begin{array}{l}\text { Direction and } \\
\text { significance } \\
\text { of correlation } \\
\text { with serum } \\
\text { corticosterone } \\
(P)\end{array}$ \\
\hline \multicolumn{5}{|l|}{$\begin{array}{l}\text { Clone } \\
\text { location } \\
\text { number }\end{array}$} \\
\hline 376 & $\begin{array}{l}\text { Insulin-like-growth factor-binding } \\
\text { protein } 1 \text { (Igfbp1) }\end{array}$ & 404595 & $-6 \cdot 2$ to $1 \cdot 3$ & $\uparrow 0.0093$ \\
\hline 1310 & Stress-induced protein (Stip) & 619418 & $-2 \cdot 7$ to $2 \cdot 0$ & $\uparrow 0.034$ \\
\hline 2559 & Hypothetical protein 1190009B22 & 355442 & $-2 \cdot 3$ to $-1 \cdot 0$ & $\uparrow 0.0061$ \\
\hline 6573 & $\begin{array}{l}\text { Pleiotropic regulator } 1 \\
\text { PRL1 homolog (Plrg1) }\end{array}$ & 776426 & $-2 \cdot 4$ to 3.0 & $\downarrow 0.030$ \\
\hline 7768 & RIKEN cDNA 1110030 N17 & 480706 & $-3 \cdot 0$ to 1.3 & $\uparrow 0.0043$ \\
\hline 8478 & Tyrosine aminotransferase (Tat) & 680259 & -3.6 to 1.5 & $\uparrow 0.014$ \\
\hline
\end{tabular}

The clone location number indicates the position on the Incyte Genomics mouse cDNA microarray chip. The distribution of the data for each of the nine microarray pairs was evaluated by the method of Chen et al. (1997), leading to calculation of the lower and upper limits of a $99 \% \mathrm{Cl}$ for the array. A total of 32 cDNAs at 35 chip locations presented array ratios which occurred outside the $99 \% \mathrm{Cl}$ for three or more data sets, a degree of variation with a very low probability of occurring by chance. The array ratios for each cDNA were examined by linear regression analysis for correlation with serum corticosterone ratios for the same animals. Of the 32 genes, five gene expression ratios correlated with serum corticosterone ratios; these results are shown above.

Table 3 Hepatic genes showing a significant correlation with serum corticosterone over nine pairs of livers

\begin{tabular}{|c|c|c|c|c|c|c|}
\hline & \multirow[b]{2}{*}{ No. } & \multicolumn{2}{|c|}{ Correlation } & \multicolumn{3}{|c|}{$\begin{array}{l}\text { Ratio expression giving } \\
\text { most significant correlation }\end{array}$} \\
\hline & & Positive & Negative & Direct & Log & Reciprocal \\
\hline $\begin{array}{l}\text { Category } \\
\text { (1) Significant without lower } \\
\text { extreme value }\end{array}$ & 83 & 76 & 7 & 15 & 64 & 4 \\
\hline $\begin{array}{l}\text { (2) Significant only with inclusion } \\
\text { of the lower extreme value }\end{array}$ & 58 & 36 & 22 & 0 & 2 & 57 \\
\hline Total & 141 & 112 & 29 & 15 & 66 & 61 \\
\hline
\end{tabular}

The nine serum corticosterone ratios included eight that were spaced as a continuum over regular intervals, plus a ninth that was markedly lower; the latter is referred to as the lower extreme value. Gene array ratios were examined for correlation with the serum corticosterone ratios from the same animals, with a cut-off of $r=0.8, \sim P=0.01$. The set was queried with the corticosterone ratios calculated in three different ways: as a direct ratio, as a log of the direct ratio, and as a format where ratios $<1.0$ were utilized as reciprocals, to mimic the format of the array ratios. These processes yielded 141 significantly correlated genes. These were further subdivided into those that maintained a significant correlation even when the lower extreme value was omitted (category 1) and those that were significantly correlated only with inclusion of the lower extreme value (category 2 ).

ratios. These are designated category 1 . The remaining 58 gene ratios (category 2; Table 5) correlated with corticosterone ratios only when the lower extreme value was included and so were most likely related to more marked differences in corticosterone. In both Tables 4 and 5, the genes are presented in approximate rank order according to the magnitude of the array ratios. 
Table 4 Hepatic genes correlating with serum corticosterone, still with significance after omission of lower extreme value

\begin{tabular}{|c|c|c|c|c|c|c|}
\hline \multirow{4}{*}{$\begin{array}{l}\text { Clone } \\
\text { location } \\
\text { number } \\
376\end{array}$} & \multirow[b]{2}{*}{ Clone name } & \multirow{2}{*}{$\begin{array}{l}\text { I.M.A.G.E. } \\
\text { clone } \\
\text { identification }\end{array}$} & \multirow[b]{2}{*}{ Function } & \multirow{2}{*}{$\begin{array}{l}\text { Correlation } \\
\text { with } \\
\text { corticosterone }\end{array}$} & \multicolumn{2}{|c|}{ Gene ratios } \\
\hline & & & & & \multirow[t]{2}{*}{$\# \geqslant 1.5$} & \multirow[t]{2}{*}{$\# \geqslant 2 \cdot 0$} \\
\hline & & & & & & \\
\hline & $\begin{array}{l}\text { Insulin-like growth factor- } \\
\text { binding protein-1 (Igfbp1) }\end{array}$ & 404595 & $\begin{array}{l}\text { Regulates in vivo activity } \\
\text { of IGF-I, usually negatively }\end{array}$ & $\uparrow$ & 6 & 5 \\
\hline 8478 & $\begin{array}{l}\text { Tyrosine aminotransferase } \\
\text { (Tat) }\end{array}$ & 680259 & Metabolism & $\uparrow$ & 5 & 3 \\
\hline 7768 & $\begin{array}{l}\text { Hypothetical protein } \\
\text { MGC36388 }\end{array}$ & 480706 & Unknown & $\uparrow$ & 3 & 2 \\
\hline 4163 & $\begin{array}{l}\text { Carnitine palmitoyl } \\
\text { transferase } 1 \text {, liver (Cpt1a) }\end{array}$ & 737898 & Phospholipid metabolism & $\uparrow$ & 3 & 1 \\
\hline 4649 & $\begin{array}{l}\text { Translocator of inner } \\
\text { mitochondrial membrane } \\
17 \mathrm{kDa} \text {, a (Timm17a) }\end{array}$ & 318134 & $\begin{array}{l}\text { Preprotein import } \\
\text { machinery component }\end{array}$ & $\downarrow$ & 3 & 1 \\
\hline 2435 & $\begin{array}{l}\text { RIKEN cDNA } 1110033 E 03 \\
\text { gene }\end{array}$ & 333669 & Unknown & $\uparrow$ & 3 & 0 \\
\hline 8505 & $\begin{array}{l}\text { Formininotransferase } \\
\text { cyclodeaminase (Ftcd) }\end{array}$ & 680146 & $\begin{array}{l}\text { Has both transferase and } \\
\text { deaminase activity; links } \\
\text { histidine with folate } \\
\text { metabolism }\end{array}$ & $\uparrow$ & 3 & 0 \\
\hline 2559 & EST & 355442 & Unknown & $\downarrow$ & 2 & 1 \\
\hline 2022 & $\begin{array}{l}\text { RIKEN cDNA } \\
\text { 1200014D15 gene }\end{array}$ & 748958 & Unknown & $\uparrow$ & 2 & 0 \\
\hline 2999 & RIKEN cDNA $1110036 \mathrm{H} 21$ & 459538 & Unknown & $\uparrow$ & 2 & 0 \\
\hline 3060 & EST & 466788 & Unknown & $\uparrow$ & 2 & 0 \\
\hline 3506 & $\begin{array}{l}\text { Zinc finger protein } 103 \\
\text { (Zfp103) }\end{array}$ & 596277 & $\begin{array}{l}\text { Presumed transcription } \\
\text { factor }\end{array}$ & $\uparrow$ & 2 & 0 \\
\hline 3953 & $\begin{array}{l}\text { Proline dehydrogenase } \\
\text { (oxidase) } 2 \text { (Prodh2) }\end{array}$ & 676559 & Proline metabolism & $\uparrow$ & 2 & 0 \\
\hline 6673 & $\begin{array}{l}\text { Williams-Beuren } \\
\text { syndrome chromosome } \\
\text { region } 14 \text { homolog } \\
\text { (human) (Wbscr14) }\end{array}$ & 521951 & Transcriptional repressor & $\uparrow$ & 2 & 0 \\
\hline 5854 & Eph receptor A3 (Epha3) & 635020 & Lymphoid function & $\downarrow$ & 1 & 1 \\
\hline 6237 & $\begin{array}{l}\text { Peroxisomal trans-2-enoyl- } \\
\text { CoA reductase (Pecr) }\end{array}$ & 680935 & Metabolism & $\uparrow$ & 1 & 1 \\
\hline 8796 & $\begin{array}{l}\text { Butyryl coenzyme A } \\
\text { synthetase } 1 \text { (Bucs1) }\end{array}$ & 748351 & Mitochondria metabolism & $\uparrow$ & 1 & 1 \\
\hline 189 & $\begin{array}{l}\text { DNA segment, Chr 2, } \\
\text { ERATO Doi 120, } \\
\text { expressed }\end{array}$ & 651903 & Unknown & $\uparrow$ & 1 & 0 \\
\hline 2990 & $\begin{array}{l}\text { EST weakly similar to } \mathrm{T} \\
\text { lymphoma oncogene } \\
\text { protein }\end{array}$ & 463157 & Unknown & $\downarrow$ & 1 & 0 \\
\hline 3580 & $\begin{array}{l}\text { RIKEN cDNA 0710008A13 } \\
\text { gene }\end{array}$ & 634469 & Unknown & $\uparrow$ & 1 & 0 \\
\hline 3929 & Aconitase 1 (Aco1) & 677092 & Metabolism & $\uparrow$ & 1 & 0 \\
\hline 4171 & $\begin{array}{l}\text { Cerebellar postnatal } \\
\text { development protein } 1 \\
\text { (Cpd1) }\end{array}$ & 736660 & $\begin{array}{l}\text { Assoiated with cerebellum } \\
\text { development }\end{array}$ & $\uparrow$ & 1 & 0 \\
\hline 6961 & $\begin{array}{l}\text { Heterogeneous nuclear } \\
\text { ribonucleoprotein A2/B1 } \\
\text { (Hnrpa2b1) }\end{array}$ & 315740 & $\begin{array}{l}\text { Pre-mRNA processing, } \\
\text { telomere regulation }\end{array}$ & $\uparrow$ & 1 & 0 \\
\hline
\end{tabular}


Table 4 Continued

\begin{tabular}{|c|c|c|c|c|c|c|}
\hline & & & & Correlation & Gene $r$ & atios \\
\hline & Clone name & identification & Function & corticosterone & $\# \geqslant 1.5$ & $\# \geqslant 2.0$ \\
\hline $\begin{array}{l}\text { Clone } \\
\text { location } \\
\text { number }\end{array}$ & & & & & & \\
\hline 7039 & $\begin{array}{l}\text { RIKEN cDNA } 1300001 / 01 \\
\text { gene }\end{array}$ & 373505 & Unknown & $\uparrow$ & 1 & 0 \\
\hline 7120 & $\begin{array}{l}\text { Phytanoyl-CoA } \\
\text { hydroxylase (Phyh) }\end{array}$ & 403728 & $\begin{array}{l}\text { Peroxisomal metabolism } \\
\text { of phytanic acid }\end{array}$ & $\uparrow$ & 1 & 0 \\
\hline 7614 & $\begin{array}{l}\text { Pescadillo homolog } 1 \text {, } \\
\text { containing breast cancer } \\
\text { gene } 1 \text { carboxyterminal } \\
\text { (BRCT) domain } \\
\text { (zebrafish) (Pes1) }\end{array}$ & 477900 & $\begin{array}{l}\text { Cell cycle, DNA repair; } \\
\text { may be necessary for } \\
\text { oncogenic transformation } \\
\text { and tumor progression }\end{array}$ & $\uparrow$ & 1 & 0 \\
\hline 7790 & $\begin{array}{l}\text { Protein distantly related to } \\
\text { the calcium channel } \\
\text { gamma subunit family } \\
\text { (Pr1) }\end{array}$ & 571643 & $\begin{array}{l}\text { Stabilization of inactive } \\
\text { calcium channels }\end{array}$ & $\uparrow$ & 1 & 0 \\
\hline 8202 & $\begin{array}{l}\text { Hypothetical protein } \\
\text { MGC38585 }\end{array}$ & 638204 & Unknown & $\uparrow$ & 1 & 0 \\
\hline 8560 & $\begin{array}{l}\text { Calcium-binding protein, } \\
\text { intestinal (Cai) }\end{array}$ & 695696 & $\begin{array}{l}\text { Protein disulfide } \\
\text { isomerase, endoplasmic } \\
\text { reticulum }\end{array}$ & $\uparrow$ & 1 & 0 \\
\hline 8564 & $\begin{array}{l}\text { Ribosomal protein S5 } \\
\text { (Rps5) }\end{array}$ & 696769 & Protein synthesis & $\uparrow$ & 1 & 0 \\
\hline 8676 & $\begin{array}{l}\text { Cis-retinol/3alpha } \\
\text { hydroxysterol short-chain } \\
\text { dehydrogenase-like } \\
\text { (Crad-L) }\end{array}$ & 747207 & $\begin{array}{l}\text { Regulates production of } \\
\text { retinol and testosterone } \\
\text { metabolite; gene } \\
\text { expression }\end{array}$ & $\uparrow$ & 1 & 0 \\
\hline 8936 & $\begin{array}{l}\text { Histidine triad nucleotide } \\
\text { bonding protein (Hint) }\end{array}$ & 533117 & Adenosine hydrolase? & $\uparrow$ & 1 & 0 \\
\hline 176 & $\begin{array}{l}\text { Expressed sequence } \\
\text { AL022671 }\end{array}$ & 335302 & Unknown & $\uparrow$ & 0 & 0 \\
\hline 235 & $\begin{array}{l}\text { Peroxisome biogenesis } \\
\text { factor } 16 \text { (Pex16) }\end{array}$ & 350336 & $\begin{array}{l}\text { Peroxisome biosynthesis } \\
\text { and integrity }\end{array}$ & $\uparrow$ & 0 & 0 \\
\hline 470 & $\begin{array}{l}\text { RIKEN cDNA 1110018G07 } \\
\text { gene }\end{array}$ & 422206 & Unknown & $\uparrow$ & 0 & 0 \\
\hline 749 & $\begin{array}{l}\text { Peroxisomal biogenesis } \\
\text { Factor } 3 \text { (Pex3) }\end{array}$ & 463255 & $\begin{array}{l}\text { Biogenesis of } \\
\text { peroxisomes }\end{array}$ & $\uparrow$ & 0 & 0 \\
\hline 1060 & $\begin{array}{l}\text { RIKEN cDNA } 0610038 K 03 \\
\text { gene }\end{array}$ & 492407 & Unknown & $\uparrow$ & 0 & 0 \\
\hline 1192 & $\begin{array}{l}\text { Inositol hexaphosphate } \\
\text { kinase } 1 \text { (Ihpk1) }\end{array}$ & 580257 & $\begin{array}{l}\text { Releases calcium from } \\
\text { intracellular stores }\end{array}$ & $\uparrow$ & 0 & 0 \\
\hline 1529 & $\begin{array}{l}\text { Nuclear factor of activated } \\
\text { T cells, cytoplasmic } 2 \\
\text { (Nfatc2) }\end{array}$ & 850163 & $\begin{array}{l}\text { Proinflammatory } \\
\text { transcription factor }\end{array}$ & $\uparrow$ & 0 & 0 \\
\hline 1582 & RIKEN cDNA $1700021 \mathrm{~K} 19$ & 890852 & Unknown & $\downarrow$ & 0 & 0 \\
\hline 1717 & $\begin{array}{l}\text { EST, moderately similar to } \\
\text { rat amine oxidase } \\
\text { (flavin-containing) B } \\
\text { (monoamine oxidase) }\end{array}$ & 680958 & $\begin{array}{l}\text { Metabolism, } \\
\text { neurotransmission }\end{array}$ & $\uparrow$ & 0 & 0 \\
\hline 1935 & $\begin{array}{l}\text { Scavenger receptor class } \\
\text { B, member } 2 \text { (Scarb2) }\end{array}$ & 747497 & $\begin{array}{l}\text { Mediates cholesterol } \\
\text { uptake }\end{array}$ & $\downarrow$ & 0 & 0 \\
\hline 1941 & $\begin{array}{l}\text { secretory protein } 14 \\
\text { (SEC14)-like } 2 \\
\text { (S. cerevisiae) (Sec14I2) }\end{array}$ & 747543 & $\begin{array}{l}\text { Carrier protein, may have } \\
\text { transcriptional activity }\end{array}$ & $\uparrow$ & 0 & 0 \\
\hline
\end{tabular}


Table 4 Continued

\begin{tabular}{|c|c|c|c|c|c|c|}
\hline \multirow{4}{*}{$\begin{array}{l}\text { Clone } \\
\text { location } \\
\text { number } \\
2064\end{array}$} & \multirow[b]{2}{*}{ Clone name } & \multirow{2}{*}{$\begin{array}{l}\text { I.M.A.G.E. } \\
\text { clone } \\
\text { identification }\end{array}$} & \multirow[b]{2}{*}{ Function } & \multirow{2}{*}{$\begin{array}{l}\text { Correlation } \\
\text { with } \\
\text { corticosterone }\end{array}$} & \multicolumn{2}{|c|}{ Gene ratios } \\
\hline & & & & & \multirow[t]{2}{*}{$\# \geqslant 1.5$} & \multirow[t]{2}{*}{$\# \geqslant 2 \cdot 0$} \\
\hline & & & & & & \\
\hline & $\begin{array}{l}\text { Glutathione S transferase } \\
\text { alpha } 3 \text { (GSTa3) }\end{array}$ & 766582 & Anti-oxidant, catabolism & $\uparrow$ & 0 & 0 \\
\hline 2294 & $\begin{array}{l}\text { Serine/threonine kinase } 11 \\
\text { (Stk11) }\end{array}$ & 933770 & $\begin{array}{l}\text { Signaling; putative tumor } \\
\text { suppressor }\end{array}$ & $\uparrow$ & 0 & 0 \\
\hline 2825 & $\begin{array}{l}\text { Transmembrane protein } 4 \\
\text { (Tmem4) }\end{array}$ & 438550 & Unknown & $\uparrow$ & 0 & 0 \\
\hline 2850 & $\begin{array}{l}\text { RIKEN cDNA } 0710001 \mathrm{~K} 01 \\
\text { gene }\end{array}$ & 424968 & Unknown & $\uparrow$ & 0 & 0 \\
\hline 3045 & $\begin{array}{l}\text { Mitochondrial ribosomal } \\
\text { protein L15 (Mrpl15) }\end{array}$ & 464084 & Protein synthesis & $\uparrow$ & 0 & 0 \\
\hline 3143 & $\begin{array}{l}\text { Phosphatidylinositol } \\
\text { transfer protein, beta } \\
\text { (Pitpnb) }\end{array}$ & 476642 & $\begin{array}{l}\text { Catalyzes the transfer of } \\
\text { phosphotidylinositol and } \\
\text { phosphotidylchloride } \\
\text { between membranes }\end{array}$ & $\uparrow$ & 0 & 0 \\
\hline 3229 & $\begin{array}{l}\text { cDNA sequence } \\
\text { BC002318 }\end{array}$ & 480204 & Unknown & $\uparrow$ & 0 & 0 \\
\hline 3239 & $\begin{array}{l}\text { LIM and Sh3 protein } 1 \\
\text { (Lasp1) }\end{array}$ & 482313 & $\begin{array}{l}\text { Involved in CAMP } \\
\text { signaling; ion transport; } \\
\text { regulation of cytoskeleton; } \\
\text { amplified in breast } \\
\text { cancers }\end{array}$ & $\uparrow$ & 0 & 0 \\
\hline 3305 & $\begin{array}{l}\text { NADH dehydrogenase } \\
\text { (ubiquinone) Fe-S protein } \\
2 \text { (Ndusf2) }\end{array}$ & 572585 & $\begin{array}{l}\text { Mitochondrial electron } \\
\text { transport; metabolism }\end{array}$ & $\uparrow$ & 0 & 0 \\
\hline 3312 & $\begin{array}{l}\text { Isocitrate dehydrogenase } \\
3(\mathrm{NAD}+) \text { beta (Idh3b) }\end{array}$ & 570685 & Metabolism & $\uparrow$ & 0 & 0 \\
\hline 3325 & CDC-like kinase 2 (Clk2) & 492518 & $\begin{array}{l}\text { Autophosphorylating } \\
\text { kinase; possibly involved } \\
\text { in mRNA splicing }\end{array}$ & $\uparrow$ & 0 & 0 \\
\hline 3382 & $\begin{array}{l}\text { Regenerating islet-derived } \\
3 \text { gamma (Reg3g) }\end{array}$ & 575773 & $\begin{array}{l}\text { Possible role in islet } \\
\beta \text {-cells }\end{array}$ & $\uparrow$ & 0 & 0 \\
\hline 3455 & $\begin{array}{l}\text { Acid phosphatase } 6 \\
\text { lysophosphatidic (Acp6) }\end{array}$ & 582668 & Catabolism & $\uparrow$ & 0 & 0 \\
\hline 3480 & $\begin{array}{l}\text { EST, weakly similar to } \\
\text { beta-tubulin cofactor } \mathrm{E} \\
\text { (H. sapiens) }\end{array}$ & 583526 & Tubulin folding & $\uparrow$ & 0 & 0 \\
\hline 3520 & $\begin{array}{l}\text { CDNA sequence } \\
\text { BC003281 }\end{array}$ & 596556 & Unknown & $\uparrow$ & 0 & 0 \\
\hline 3579 & $\begin{array}{l}\text { Expressed sequence } \\
\text { Al662535 }\end{array}$ & 636324 & Unknown & $\uparrow$ & 0 & 0 \\
\hline 3626 & $\begin{array}{l}\text { Alcohol dehydrogenase } 5 \\
\text { (Adh5) }\end{array}$ & 636207 & Metabolism, catabolism & $\uparrow$ & 0 & 0 \\
\hline 3640 & $\begin{array}{l}\text { Syntaxin 4A (placental) } \\
\text { (Stx4a) }\end{array}$ & 634982 & $\begin{array}{l}\text { Membrane protein } \\
\text { involved in exocytosis }\end{array}$ & $\uparrow$ & 0 & 0 \\
\hline 3702 & $\begin{array}{l}\text { Expressed sequence } \\
\text { Al465155 }\end{array}$ & 639991 & Unknown & $\uparrow$ & 0 & 0 \\
\hline 3851 & $\begin{array}{l}\text { Eukaryotic translation } \\
\text { initiation factor } 3 \text { (Eif3) }\end{array}$ & 889816 & Translation initiation & $\uparrow$ & 0 & 0 \\
\hline
\end{tabular}


Table 4 Continued

\begin{tabular}{|c|c|c|c|c|c|c|}
\hline \multirow[b]{3}{*}{$\begin{array}{l}\text { Clone } \\
\text { location } \\
\text { number }\end{array}$} & \multirow[b]{2}{*}{ Clone name } & \multirow{2}{*}{$\begin{array}{l}\text { I.M.A.G.E. } \\
\text { clone } \\
\text { identification }\end{array}$} & \multirow[b]{2}{*}{ Function } & \multirow{2}{*}{$\begin{array}{l}\text { Correlation } \\
\text { with } \\
\text { corticosterone }\end{array}$} & \multicolumn{2}{|c|}{ Gene ratios } \\
\hline & & & & & $\geqslant 1.5$ & $\geqslant 2 \cdot 0$ \\
\hline & & & & & & \\
\hline 4108 & $\begin{array}{l}\text { Beta-1,3- } \\
\text { glucuronyltransferase } 3 \\
\text { (glucuronosyltransferase I) } \\
\text { (B3gat3) }\end{array}$ & 734282 & Catabolism & $\uparrow$ & 0 & 0 \\
\hline 4158 & $\begin{array}{l}\text { Ankyrin repeat } \\
\text { domain-containing SOCS } \\
\text { box protein } 13 \text { (Acb13) }\end{array}$ & 735500 & $\begin{array}{l}\text { Couples suppressor of } \\
\text { cytokine signalling (SOCS) } \\
\text { proteins and their binding } \\
\text { partners with the elongin } \\
\mathrm{B} \text { and } \mathrm{C} \text { complex, possibly } \\
\text { targeting them for } \\
\text { degradation }\end{array}$ & $\uparrow$ & 0 & 0 \\
\hline 4224 & $\begin{array}{l}\text { Expressed sequence } \\
\text { R74866 }\end{array}$ & 749778 & Unknown & $\uparrow$ & 0 & 0 \\
\hline 4374 & Ubinuclein 1 (Ubn1) & 820195 & $\begin{array}{l}\text { Interacts with the basic } \\
\text { domains of transcription } \\
\text { factors EB1 and c-Jun } \\
\text { and competes with their } \\
\text { binding to the AP1 } \\
\text { consensus site }\end{array}$ & $\uparrow$ & 0 & 0 \\
\hline 4766 & $\begin{array}{l}\text { RIKEN cDNA } \\
5430429 \text { M05 gene }\end{array}$ & 353294 & Unknown & $\downarrow$ & 0 & 0 \\
\hline 4813 & $\begin{array}{l}\text { Solute carrier family } 25 \\
\text { (mitochondrial carrier; } \\
\text { oxoglutarate carrier), } \\
\text { member } 11 \text { (SIc25all) }\end{array}$ & 367801 & Mitochondrial function & $\uparrow$ & 0 & 0 \\
\hline 5560 & $\begin{array}{l}\text { Tripartite motif protein } 24 \\
\text { (Trim24) }\end{array}$ & 571091 & $\begin{array}{l}\text { Transcriptional } \\
\text { intermediary factor }\end{array}$ & $\uparrow$ & 0 & 0 \\
\hline 5638 & $\begin{array}{l}\text { Expressed sequence } \\
\text { AU042952 }\end{array}$ & 574974 & Unknown & $\uparrow$ & 0 & 0 \\
\hline 6231 & Glucosidase 1 (Gcs1) & 680150 & $\begin{array}{l}\text { First enzyme in the } \\
\mathrm{N} \text {-linked oligosaccharide } \\
\text { processing pathway }\end{array}$ & $\uparrow$ & 0 & 0 \\
\hline 6464 & $\begin{array}{l}\text { DNA segment, Chr 16, } \\
\text { human D22S680E, } \\
\text { expressed }\end{array}$ & 750147 & Unknown & $\uparrow$ & 0 & 0 \\
\hline 7055 & SH3-binding kinase (Sbk) & 389034 & Signaling & $\uparrow$ & 0 & 0 \\
\hline 7136 & $\begin{array}{l}\text { Transmembrane } 9 \\
\text { superfamily member } 1 \\
\text { (Tm9sf1) }\end{array}$ & 404535 & Vesicle transport? & $\uparrow$ & 0 & 0 \\
\hline 7475 & RIKEN cDNA 2610003B19 & 456543 & Unknown & $\uparrow$ & 0 & 0 \\
\hline 7656 & $\begin{array}{l}\text { Translin-associated factor } \\
\text { X (Tsnax) }\end{array}$ & 476185 & $\begin{array}{l}\text { A DNA-binding protein that } \\
\text { binds consensus } \\
\text { sequences at breakpoint } \\
\text { junctions of chromosomal } \\
\text { translocations }\end{array}$ & $\uparrow$ & 0 & 0 \\
\hline 7842 & $\begin{array}{l}\text { WD repeat domain } 1 \\
\text { (War1) }\end{array}$ & 493109 & $\begin{array}{l}\text { Actin-binding protein, } \\
\text { putatively involved in } \\
\text { protein interaction }\end{array}$ & $\uparrow$ & 0 & 0 \\
\hline 7846 & EST & 484315 & Unknown & $\uparrow$ & 0 & 0 \\
\hline
\end{tabular}


Table 4 Continued

\begin{tabular}{|c|c|c|c|c|c|c|}
\hline \multirow[b]{3}{*}{$\begin{array}{l}\text { Clone } \\
\text { location } \\
\text { number }\end{array}$} & \multirow[b]{2}{*}{ Clone name } & \multirow{2}{*}{$\begin{array}{l}\text { I.M.A.G.E. } \\
\text { clone } \\
\text { identification }\end{array}$} & \multirow[b]{2}{*}{ Function } & \multirow{2}{*}{$\begin{array}{l}\text { Correlation } \\
\text { with } \\
\text { corticosterone }\end{array}$} & \multicolumn{2}{|c|}{ Gene ratios } \\
\hline & & & & & $\# \geqslant 1.5$ & $\# \geqslant 2.0$ \\
\hline & & & & & & \\
\hline 8397 & $\begin{array}{l}\text { Degenerating } \\
\text { spematocyte homologue } \\
\text { (Degs) }\end{array}$ & 676578 & Lipid desaturatase & $\uparrow$ & 0 & 0 \\
\hline 8771 & $\begin{array}{l}\text { Ribosomal protein S5 } \\
\text { (Rps5) }\end{array}$ & 775645 & Protein synthesis & $\uparrow$ & 0 & 0 \\
\hline 8966 & $\begin{array}{l}\text { RIKEN cDNA 2010012D11 } \\
\text { gene }\end{array}$ & 524682 & Unknown & $\uparrow$ & 0 & 0 \\
\hline 8969 & $\begin{array}{l}\text { RIKEN cDNA } \\
2510008 \mathrm{H} 07 \text { gene }\end{array}$ & 532770 & Unknown & $\uparrow$ & 0 & 0 \\
\hline
\end{tabular}

The clone location number refers to the position on the Incyte Genomics mouse cDNA microarray chip. For each cDNA, the array ratios for nine pairs of female mouse livers were plotted against the ratios of serum corticosterone levels for the same animals. Those showing correlation at $P<0.01$ or better by linear regression analysis are listed, along with the direction of the correlation. The number of microarray ratios equal to or exceeding 1.5 and 2.0 are also shown.

The majority of the genes in category 1 showed strongest correlation with absolute or, more frequently, $\log$ corticosterone ratios; only four correlated best with the reciprocal value (Table 3 ). Most correlated positively, with seven showing a negative association (Table 4). A convention in microarray analysis is to regard ratios of \pm 1.5 as potentially significant. In category 1,32 genes included at least one ratio $\pm 1 \cdot 5$; some of these genes are illustrated in Fig. 1. The first two genes on the list, Igfbpl and tyrosine amino transferase, had multiple gene ratios $\pm 2 \cdot 0$, and had accordingly also appeared on the list of significant changes based on the analysis presented in Table 2 . However, even genes with only one ratio value \pm 1.5 showed highly significant correlations with serum corticosterone ratios, for example, pescadillo homologue $1(P=0 \cdot 0055)$, heterogeneous nuclear ribonucleoprotein $A 2 / B 1(P=0.0019)$, cis retinol-androgen dehydrogenase $(P=0.0043)$, proline oxidase $2(P=0 \cdot 0045)$, and histidine triad nucleotide-binding protein $(P=0 \cdot 0033)$ (Fig. 1). Of these, proline oxidase is known to be regulated by corticosterone (Kowaloff et al. 1977). The heterogeneous nuclear ribonucleoprotein A2/B1 belongs to a class of molecules known to interact with the glucocorticoid receptor (Eggert et al. 2001). Thus, correlations of expression of these genes with serum corticosterone are plausible.

Fifty-one genes in category 1 had no microarray ratio \pm 1.5 (Table 4 ). In spite of presentation exclusively of low gene expression ratios, many of the correlations showed very highly significant correlations between cDNA ratios and serum corticosterone, as illustrated in Fig. 2. Several of these are known to be regulated by glucocorticoids: nuclear factor of activated $T$ cells $(P=0 \cdot 0028$, not shown $)$ (Refojo et al. 2001), glutathione $S$ transferase a3 $(P=0 \cdot 0019)$ (Falkner et al. 2001), alcohol dehydrogenase $5(P=0 \cdot 0030)$ (Edenberg 2000), and glucosidase 1 $(P=0.0037$, not shown) (Kalamidas \& Kotoulas $2000)$. The protein product of scavenger receptor class $B(P=0.0063)$ has an important role in regulating plasma levels of cholesterol for use in glucocorticoid synthesis (Galman et al. 2002, Malerod et al. 2002).

Category 2 genes included many correlating negatively with corticosterone ratios, and almost all showed strongest correlation when the reciprocal corticosterone ratio values were used (Table 3). Fourteen genes in this class had more than one ratio $\pm 1.5 \mathrm{and} /$ or one or more $\geq 2 \cdot 0$ (Table 5 ). Nevertheless, some genes with only one ratio $\pm 1 \cdot 5$ had very highly significant correlations between gene and corticosterone ratios (Fig. 3), for example, interleukin 15 receptor $(P=0 \cdot 0001)$, fibroblast growth factor receptor $(P<0.0001)$, nuclear factor, erythroid derived $(P=0.0001)$, and programmed cell death $8(P<0 \cdot 0001)$. Genes in this group known to be influenced by glucocorticoids include fibroblast growth factor receptor (Riva et al. 1998) and the myeloblastosis oncogene, myb (Eastman-Reks \& Vedeckis 1986). 
Table 5 Hepatic genes correlating with serum corticosterone, significant only with inclusion of the lower extreme value

\begin{tabular}{|c|c|c|c|c|c|c|}
\hline \multirow{4}{*}{$\begin{array}{l}\text { Clone } \\
\text { location } \\
\text { number } \\
5604\end{array}$} & \multirow[b]{2}{*}{ Clone name } & \multirow{2}{*}{$\begin{array}{l}\text { I.M.A.G.E. } \\
\text { clone } \\
\text { identification }\end{array}$} & \multirow[b]{2}{*}{ Function } & \multirow{2}{*}{$\begin{array}{l}\text { Correlation } \\
\text { with } \\
\text { corticosterone }\end{array}$} & \multicolumn{2}{|c|}{ Gene ratios } \\
\hline & & & & & \multirow[t]{2}{*}{$\# \geqslant 1.5$} & \multirow[t]{2}{*}{$\# \geqslant 2 \cdot 0$} \\
\hline & & & & & & \\
\hline & $\begin{array}{l}\text { BTB (POZ) domain } \\
\text { containing } 1 \text { (Btbd1) }\end{array}$ & 576401 & $\begin{array}{l}\text { Interacts with } \\
\text { topoisomerase } 1\end{array}$ & $\uparrow$ & 4 & 1 \\
\hline 7214 & $\begin{array}{l}\text { EST highly similar to } \\
\text { DEAD-box protein p72 }\end{array}$ & 418920 & DNA helicase & $\uparrow$ & 4 & 0 \\
\hline 4127 & RIKEN cDNA 2210403K04 & 722566 & Unknown & $\uparrow$ & 3 & 2 \\
\hline 7154 & RIKEN cDNA 1110003022 & 404057 & Unknown & $\uparrow$ & 3 & 1 \\
\hline 8236 & $\begin{array}{l}\text { Moderately similar to } \\
\text { putative integral } \\
\text { membrane transport } \\
\text { protein (USTIr) }\end{array}$ & 643257 & Solute transport? & $\uparrow$ & 3 & 1 \\
\hline 5676 & RIKEN cDNA 2610007 K22 & 573857 & Unknown & $\uparrow$ & 3 & 0 \\
\hline 8479 & RIKEN cDNA 1810018P12 & 679244 & Unknown & $\uparrow$ & 3 & 0 \\
\hline 5178 & $\begin{array}{l}\text { par-3 (partitioning } \\
\text { defective } 3 \text { ) homolog } \\
\text { (C. elegans) (Pard3) }\end{array}$ & 443916 & $\begin{array}{l}\text { Essential for asymmetric } \\
\text { cell division and polarized } \\
\text { growth }\end{array}$ & $\downarrow$ & 2 & 1 \\
\hline 5699 & $\begin{array}{l}\text { Hypothetical protein } \\
\text { MGC25977 }\end{array}$ & 578525 & Unknown & $\uparrow$ & 2 & 0 \\
\hline 2714 & RIKEN cDNA $1110006 \mid 15$ & 422123 & Unknown & $\downarrow$ & 1 & 1 \\
\hline 6313 & $\begin{array}{l}\text { Myeloblastosis oncogene } \\
\text { (Myb) }\end{array}$ & 721803 & Transcription factor & $\downarrow$ & 1 & 1 \\
\hline 6389 & Pellino 1 (Peli 1) & 718768 & $\begin{array}{l}\text { Signaling; toll } \\
\text { receptor-related protein }\end{array}$ & $\downarrow$ & 1 & 1 \\
\hline 7066 & $\begin{array}{l}\text { f-box and leucine-rich } \\
\text { repeat protein } 11 \text { (Fbxl11) }\end{array}$ & 373036 & Protein targeting? & $\downarrow$ & 1 & 1 \\
\hline 7545 & $\begin{array}{l}\text { RIKEN cDNA } \\
1200003006 \text { gene }\end{array}$ & 464280 & Unknown & $\uparrow$ & 1 & 1 \\
\hline 1071 & $\begin{array}{l}\text { Similar to hypothetical } \\
\text { protein CG2803 }\end{array}$ & 493256 & Unknown & $\uparrow$ & 1 & 0 \\
\hline 1103 & $\begin{array}{l}\text { RIKEN cDNA } \\
2610002 D 18 \text { gene }\end{array}$ & 573595 & Unknown & $\downarrow$ & 1 & 0 \\
\hline 1245 & $\begin{array}{l}\text { Expressed sequence } \\
\text { C78339 }\end{array}$ & 599069 & Unknown & $\uparrow$ & 1 & 0 \\
\hline 1578 & $\begin{array}{l}\text { NADH dehydrogenase } \\
\text { (ubiquinone) } 1 \text { alpha } \\
\text { subcomplex, } 6 \text { (14 kDa, } \\
\text { B14) (Ndufa6) }\end{array}$ & 871020 & $\begin{array}{l}\text { Mitochondrial electron } \\
\text { transport }\end{array}$ & $\uparrow$ & 1 & 0 \\
\hline 1810 & $\begin{array}{l}\text { Fibroblast growth factor } \\
\text { receptor } 1 \text { (Fgfr1) }\end{array}$ & 734032 & $\begin{array}{l}\text { Receptor; cell growth } \\
\text { control }\end{array}$ & $\downarrow$ & 1 & 0 \\
\hline 1851 & $\begin{array}{l}\text { Nuclear factor, erythoid } \\
\text { derived, } 45 \mathrm{kDa}(\mathrm{Nfe} 2)\end{array}$ & 733953 & $\begin{array}{l}\text { Presumed transcription } \\
\text { factor regulates } \\
\text { hemoglobin production }\end{array}$ & $\downarrow$ & 1 & 0 \\
\hline 1860 & $\begin{array}{l}\text { Programmed cell death } 8 \\
\text { (Pdcd8) }\end{array}$ & 719457 & Involved in apoptosis & $\uparrow$ & 1 & 0 \\
\hline 2032 & $\begin{array}{l}\text { Ubiquitin-conjugating } \\
\text { enzyme E2, J1 (Ube2j1) }\end{array}$ & 751477 & Protein regulation & $\downarrow$ & 1 & 0 \\
\hline 3938 & $\begin{array}{l}\text { EST highly similar to } \\
\text { chloride intracellular } \\
\text { channel protein p64 }\end{array}$ & 670375 & $\begin{array}{l}\text { Presumed chloride } \\
\text { transport nuclear } \\
\text { membrane }\end{array}$ & $\uparrow$ & 1 & 0 \\
\hline
\end{tabular}


Table 5 Continued

\begin{tabular}{|c|c|c|c|c|c|c|}
\hline & & & & & Gene $r$ & atios \\
\hline & Clone name & identification & Function & corticosterone & $\# \geqslant 1.5$ & $\# \geqslant 2 \cdot 0$ \\
\hline $\begin{array}{l}\text { Clone } \\
\text { location } \\
\text { number }\end{array}$ & & & & & & \\
\hline 4220 & $\begin{array}{l}\text { Inositol polyphosphate-5- } \\
\text { phospatase, } 75 \mathrm{kDa} \\
\text { (Inpp5b) }\end{array}$ & 749425 & Signaling & $\uparrow$ & 1 & 0 \\
\hline 4236 & $\begin{array}{l}\text { Nitrogen fixation gene } 1 \\
(S . \text { cerevisiae) (Nfs1) }\end{array}$ & 750126 & $\begin{array}{l}\text { Mitochondrial iron } \\
\text { transport; iron-sulfur } \\
\text { cluster }\end{array}$ & $\uparrow$ & 1 & 0 \\
\hline 4260 & $\begin{array}{l}\text { Interleukin } 15 \text { receptor, } \\
\text { alpha chain (II15ra) }\end{array}$ & 777103 & IL15 action Interleukin & $\uparrow$ & 1 & 0 \\
\hline 4561 & $\begin{array}{l}\text { M. musculus, clone } \\
\text { I.M.A.G.E.: } 5102170 \text {, } \\
\text { mRNA, partial }\end{array}$ & 761319 & Unknown & $\downarrow$ & 1 & 0 \\
\hline 566 & $\begin{array}{l}\text { Pregnancy upregulated } \\
\text { non-ubiquitously } \\
\text { expressed CaM kinase } \\
\text { (Pnck) }\end{array}$ & 834617 & Signaling & $\downarrow$ & 1 & 0 \\
\hline 715 & $\begin{array}{l}\text { Expressed sequence } \\
\text { Al194968 }\end{array}$ & 457071 & Unknown & $\downarrow$ & 1 & 0 \\
\hline 7356 & $\begin{array}{l}\text { ATP-binding cassette, } \\
\text { sub-family G (WHITE), } \\
\text { member } 4 \text { (Abcg4) }\end{array}$ & 427248 & $\begin{array}{l}\text { Expressed predominantly } \\
\text { in liver tissue; function } \\
\text { may involve cholesterol } \\
\text { transport }\end{array}$ & $\downarrow$ & 1 & 0 \\
\hline 7461 & $\begin{array}{l}\text { Cyclin D-type binding } \\
\text { protein } 1 \text { (CCNDBP1) } \\
\text { interactor (Cdpin) }\end{array}$ & 445520 & $\begin{array}{l}\text { Protein interaction; cell } \\
\text { cycle control }\end{array}$ & $\downarrow$ & 1 & 0 \\
\hline 7834 & EST & 571219 & Unknown & $\uparrow$ & 1 & 0 \\
\hline 87 & RIKEN cDNA $9030401 \mathrm{P} 18$ & 574725 & Unknown & $\uparrow$ & 1 & 0 \\
\hline 8894 & $\begin{array}{l}\text { Peroxisomal sarcosine } \\
\text { oxidase (Pso) }\end{array}$ & 790721 & Peroxisomal metabolism & $\uparrow$ & 0 & 0 \\
\hline 539 & $\begin{array}{l}\text { Transactivating region } \\
\text { (TAR) DNA binding protein } \\
\text { (Tardbp) }\end{array}$ & 427346 & $\begin{array}{l}\text { A transcriptional repressor } \\
\text { that binds to } \\
\text { chromosomally integrated } \\
\text { TAR DNA and represses } \\
\text { HIV-1 transcription }\end{array}$ & $\uparrow$ & 0 & 0 \\
\hline 852 & EST & 476972 & Unknown & $\downarrow$ & 0 & 0 \\
\hline 917 & $\begin{array}{l}\text { Expressed sequence } \\
\text { C86142 }\end{array}$ & 479186 & Unknown & $\downarrow$ & 0 & 0 \\
\hline 1040 & RIKEN cDNA 2310004N11 & 573093 & Unknown & $\downarrow$ & 0 & 0 \\
\hline 1507 & Cadherin 11 (Cdh11) & 658334 & Adhesion protein & $\uparrow$ & 0 & 0 \\
\hline 1759 & RIKEN cDNA 1110027L01 & 693341 & Unknown & $\downarrow$ & 0 & 0 \\
\hline 1896 & $\begin{array}{l}\text { Protein kinase, cAMP } \\
\text { dependent, regulatory, } \\
\text { type } 1 \text { beta (Prkar1b) }\end{array}$ & 736724 & Signal transduction & $\downarrow$ & 0 & 0 \\
\hline 2057 & $\begin{array}{l}\text { Interferon regulatory factor } \\
1 \text { (Irf1) }\end{array}$ & 777393 & $\begin{array}{l}\text { Transcription factor; } \\
\text { anti-oncogenic actions }\end{array}$ & $\uparrow$ & 0 & 0 \\
\hline 3522 & $\begin{array}{l}\text { RIKEN cDNA } \\
1700056017 \text { gene }\end{array}$ & 596719 & Unknown & $\uparrow$ & 0 & 0 \\
\hline 4201 & EST Al426782 & 737425 & Unknown & $\uparrow$ & 0 & 0 \\
\hline 4240 & $\begin{array}{l}\text { Carcinoembryonic antigen } \\
\text { (CEA)-related cell } \\
\text { adhesion molecule } 2 \\
\text { (Ceacam2) }\end{array}$ & 762299 & $\begin{array}{l}\text { Cell adhesion; } \\
\text { immunoglobulin family; } \\
\text { anti-oncogenic actions }\end{array}$ & $\uparrow$ & 0 & 0 \\
\hline
\end{tabular}


Table 5 Continued

\begin{tabular}{|c|c|c|c|c|c|c|}
\hline \multirow[b]{3}{*}{$\begin{array}{l}\text { Clone } \\
\text { location } \\
\text { number }\end{array}$} & \multirow[b]{2}{*}{ Clone name } & \multirow{2}{*}{$\begin{array}{l}\text { I.M.A.G.E. } \\
\text { clone } \\
\text { identification }\end{array}$} & \multirow[b]{2}{*}{ Function } & \multirow{2}{*}{$\begin{array}{l}\text { Correlation } \\
\text { with } \\
\text { corticosterone }\end{array}$} & \multicolumn{2}{|c|}{ Gene ratios } \\
\hline & & & & & $\# \geqslant 1.5$ & $\# \geqslant 2 \cdot 0$ \\
\hline & & & & & & \\
\hline 4452 & EST & 535794 & Unknown & $\uparrow$ & 0 & 0 \\
\hline 4904 & $\begin{array}{l}\text { Protein tyrosine kinase } 9 \\
\text { (Ptk9) }\end{array}$ & 402345 & Cell regulation & $\downarrow$ & 0 & 0 \\
\hline 5561 & $\begin{array}{l}\text { Small protein effector } 1 \text { of } \\
\text { Cdc } 42 \text { (Spec1) }\end{array}$ & 573520 & $\begin{array}{l}\text { May act as a scaffold to } \\
\text { co-ordinate and/or } \\
\text { mediate Cdc42 regulation } \\
\text { of kinase signaling and } \\
\text { cell shape changes }\end{array}$ & $\downarrow$ & 0 & 0 \\
\hline 6214 & $\begin{array}{l}\text { M. musculus, clone } \\
\text { I.M.A.G.E.: } 3597827 \text {, } \\
\text { mRNA, partial }\end{array}$ & 676898 & Unknown & $\uparrow$ & 0 & 0 \\
\hline 6811 & $\begin{array}{l}\text { M. musculus, similar to } \\
\text { tripartite motif-containing } \\
6 \text {, clone }\end{array}$ & 805046 & Signaling? & $\uparrow$ & 0 & 0 \\
\hline 7307 & $\begin{array}{l}\text { B-cell CLL/lymphoma } 11 \mathrm{~A} \\
\text { (zinc finger protein) } \\
\text { (Bcl11a) }\end{array}$ & 425021 & $\begin{array}{l}\text { May be a leukemia/ } \\
\text { lymphoma-associated } \\
\text { disease gene; } \\
\text { translocations associated } \\
\text { with B-cell malignancies } \\
\text { deregulate its expression }\end{array}$ & $\downarrow$ & 0 & 0 \\
\hline 7362 & $\begin{array}{l}\text { RIKEN cDNA } \\
\text { 2700081N06 }\end{array}$ & 426076 & Unknown & $\uparrow$ & 0 & 0 \\
\hline 7835 & $\begin{array}{l}\text { SH3-domain binding } \\
\text { protein } 5 \text { (protein tyrosine } \\
\text { kinase (BTK)-associated) } \\
\text { (Sh3bp5) }\end{array}$ & 571398 & $\begin{array}{l}\text { Inhibits the auto- and } \\
\text { transphosphorylation } \\
\text { activity of Bruton tyrosine } \\
\text { kinase }\end{array}$ & $\uparrow$ & 0 & 0 \\
\hline 8160 & $\begin{array}{l}\text { Protein tyrosine } \\
\text { phosphatase } 4 a 2 \text { (Ptp4a2) }\end{array}$ & 634539 & Signal control & $\uparrow$ & 0 & 0 \\
\hline 8312 & $\begin{array}{l}\text { A disintegrin and } \\
\text { metalloproteinase domain } \\
9 \text { (meltrin gamma) } \\
\text { (Adam9) }\end{array}$ & 644907 & $\begin{array}{l}\text { Transmembrane } \\
\text { metalloprotein; secretase? }\end{array}$ & $\uparrow$ & 0 & 0 \\
\hline 8460 & $\begin{array}{l}\text { Golgi autoantigen, golgin } \\
\text { subfamily a, } 5 \text { (Golga5) }\end{array}$ & 659182 & Golgi interactions & $\uparrow$ & 0 & 0 \\
\hline 8489 & $\begin{array}{l}\text { RIKEN cDNA } \\
2510006 \text { C20 }\end{array}$ & 693767 & Unknown & $\uparrow$ & 0 & 0 \\
\hline 8901 & $\begin{array}{l}\text { DNA segment, Chr } 4 \text {, } \\
\text { Brigham \& Women's } \\
\text { Genetics } 0593 \text { expressed }\end{array}$ & 831951 & Unknown & $\uparrow$ & 0 & 0 \\
\hline
\end{tabular}

The clone location number refers to the position on the Incyte Genomics mouse cDNA microarray chip. For each cDNA, the array ratios for nine pairs of female mouse livers were plotted against the ratios of serum corticosterone levels for the same animals. Those showing correlation at $P<0.01$ or better by linear regression analysis are listed, along with the direction of the correlation. The number of microarray ratios equal to or exceeding 1.5 and 2.0 are also shown.

There were 24 genes in category 2 that showed no ratio $\pm 1 \cdot 5$. Several of these (Fig. 4) showed highly significant correlations, and are from families with known glucocorticoid regulation: protein kinase $A$, regulatory, type $1 \beta \quad(P=0 \cdot 0002)$ (Dwivedi \& Pandey 2000), interferon regulatory factor $(P<0 \cdot 0001)$ (Franchimont et al. 2000), and cadherin $11(P<0 \cdot 0001)$ (Foty et al. 1998). 


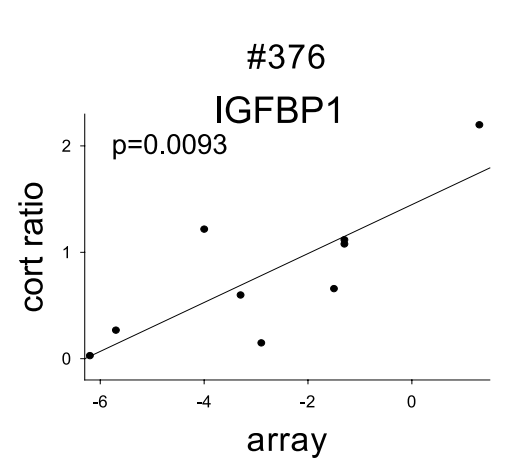

\#7614

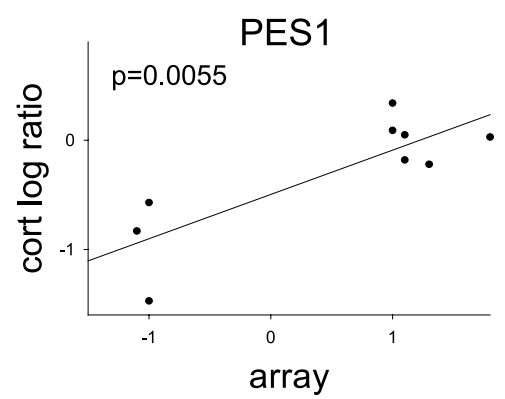

\#4163

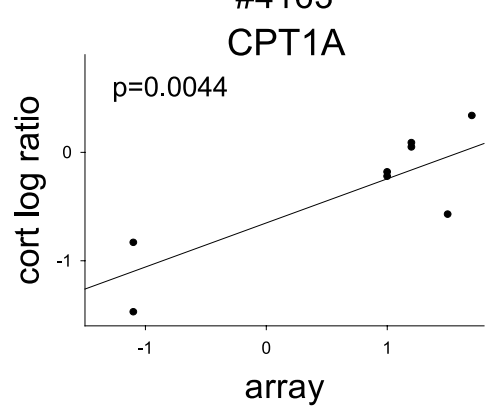

\#6673

WBSCR14

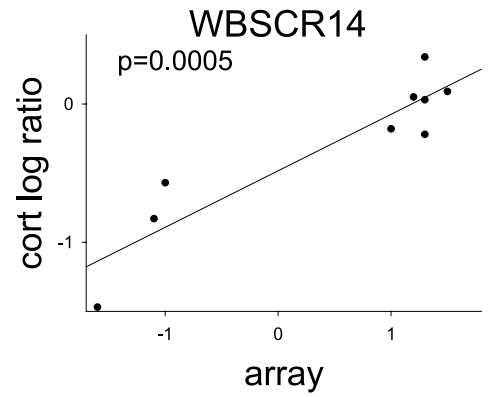

\#8478

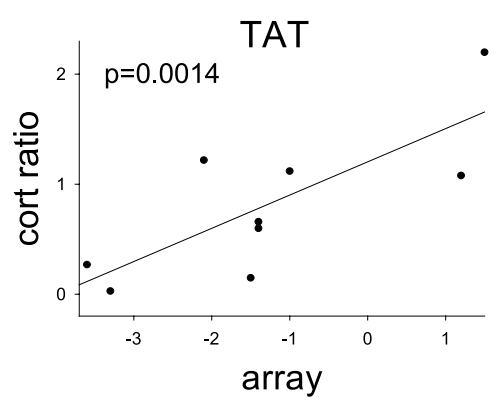

\#8676

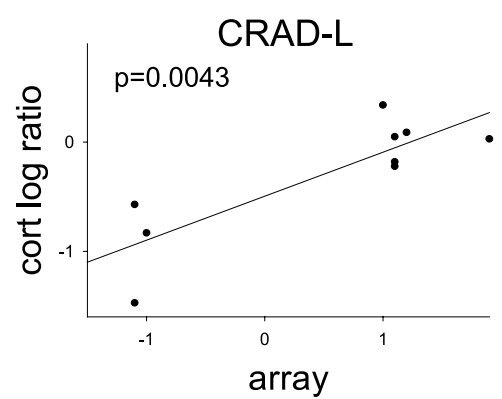

\#8936

HINT
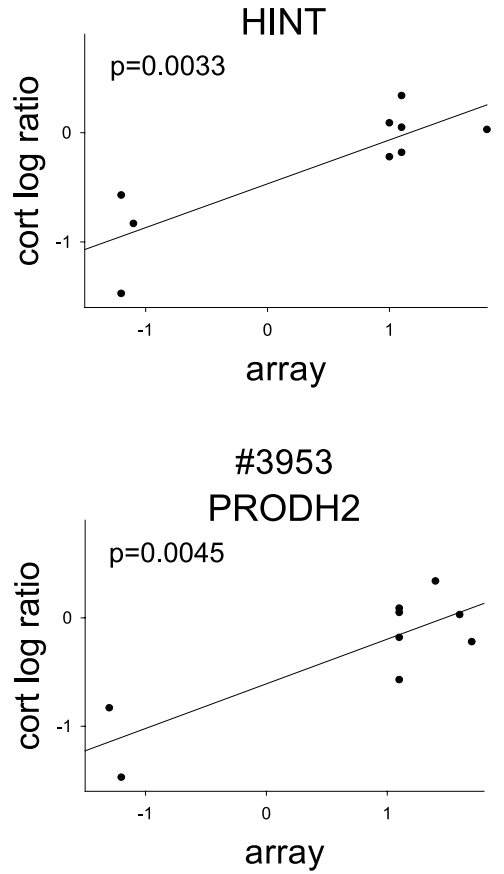

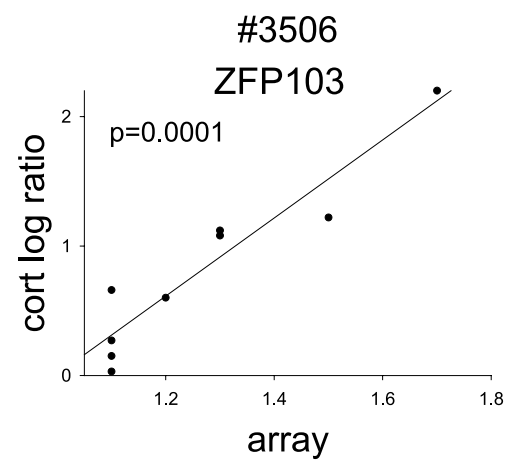

\#6961

HNRPA2B1

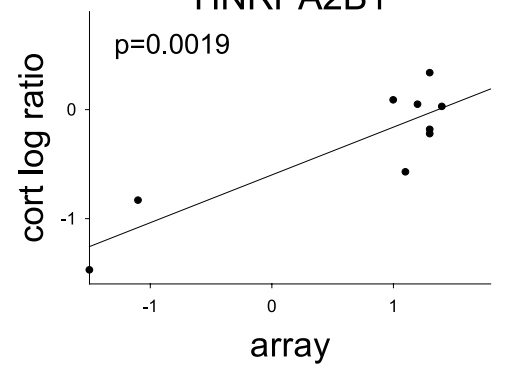

\#6237

PECR

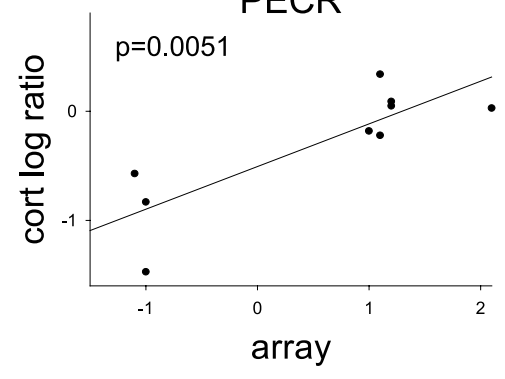

\#4649

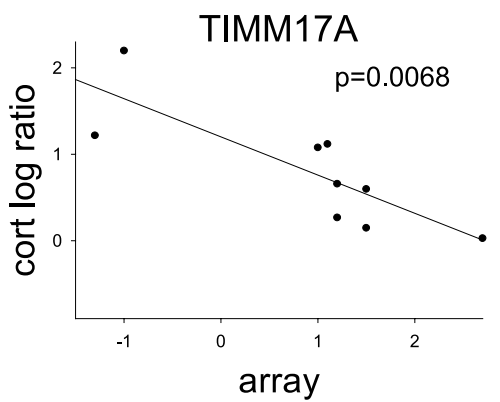

Figure 1 Representative genes showing significant correlation between microarray ratios and serum corticosterone (cort) ratios (or log corticosterone ratios), for category 1 genes with one or more gene pairs showing an array ratio of \pm 1.5 or greater. The correlation for category 1 genes was still significant when the lower extreme value was omitted. 

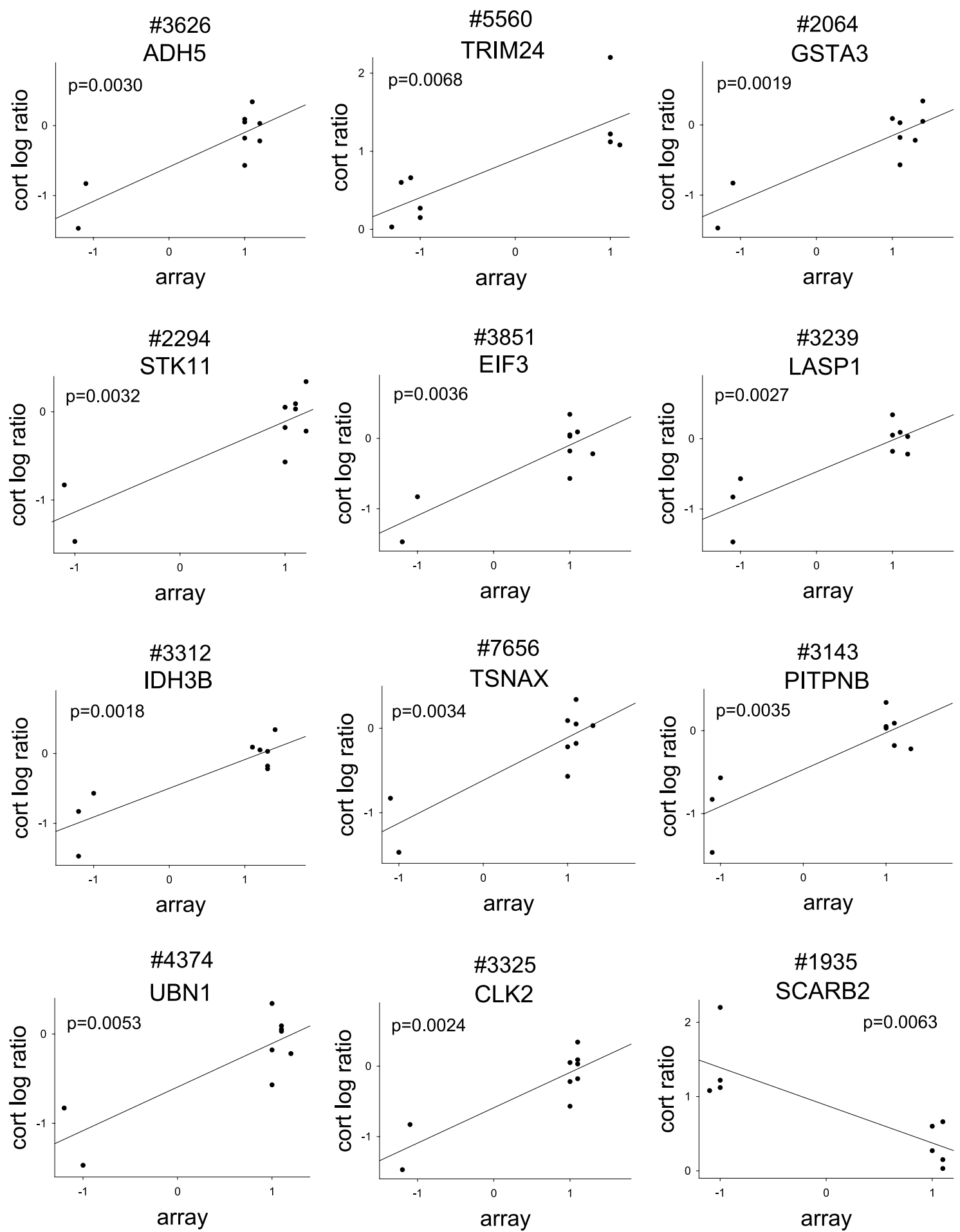

Figure 2 Representative genes showing significant correlation between microarray ratios and serum corticosterone ratios (or log corticosterone ratios), for category 1 genes with no gene pairs showing an array ratio of \pm 1.5 or greater. The correlation for category 1 genes was still significant when the lower extreme value was omitted. 

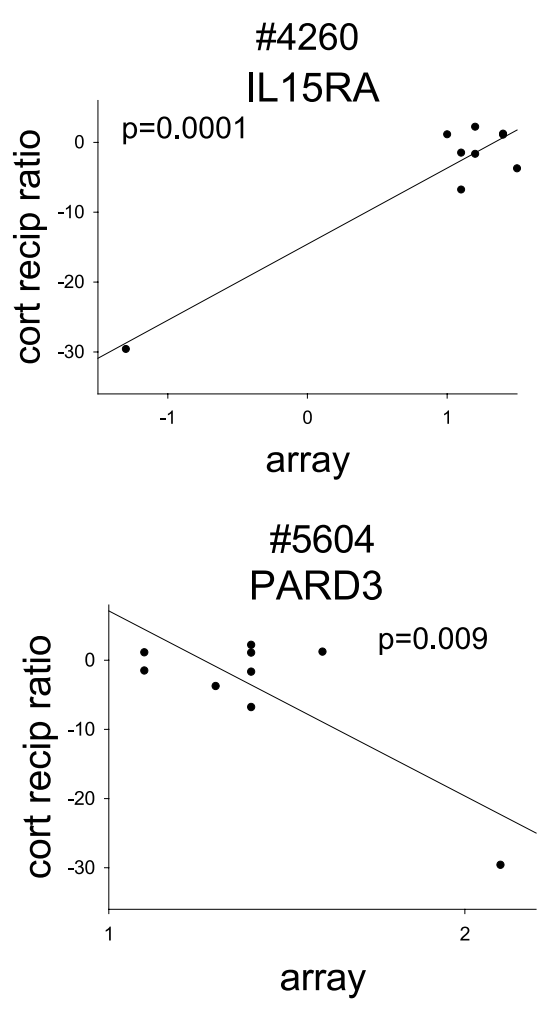

\#7066

FBXI11
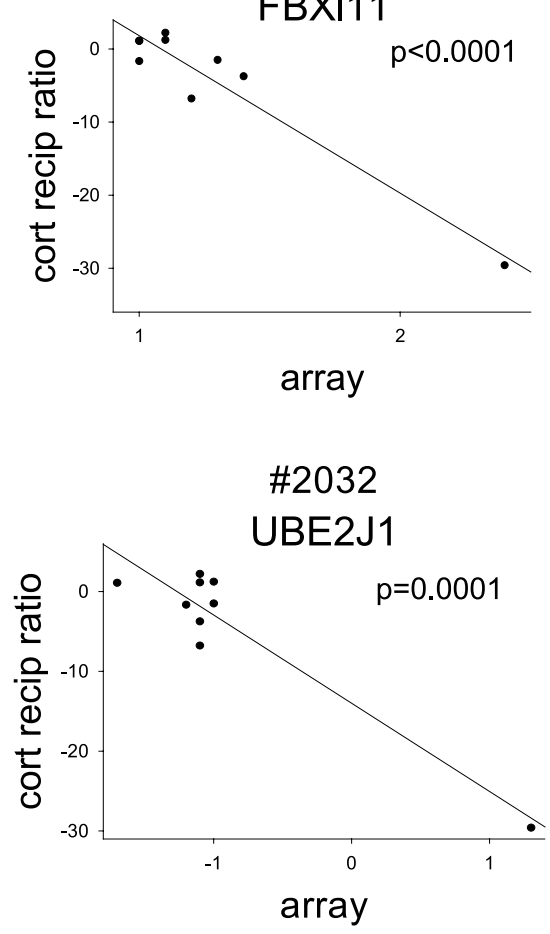

\#4220

INPP5B
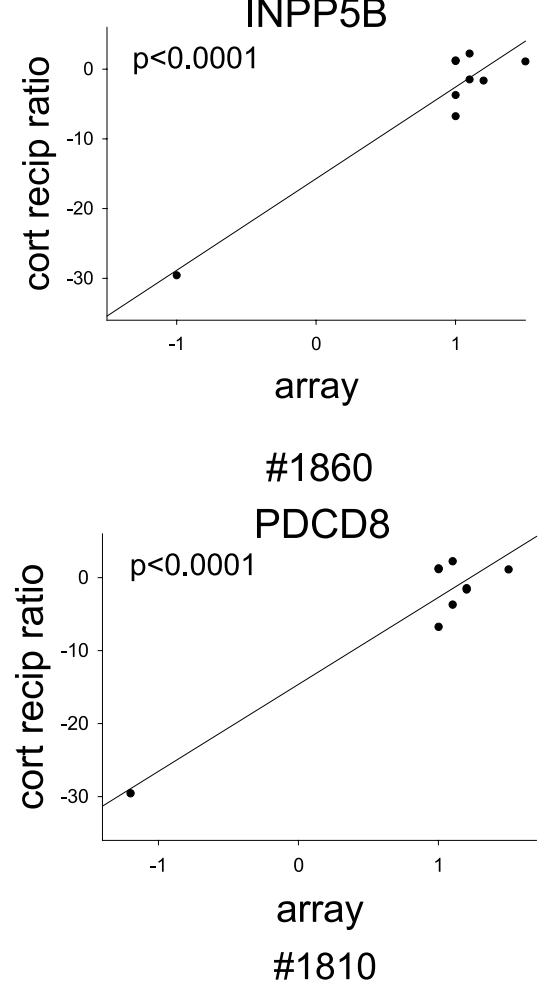

FGFR1
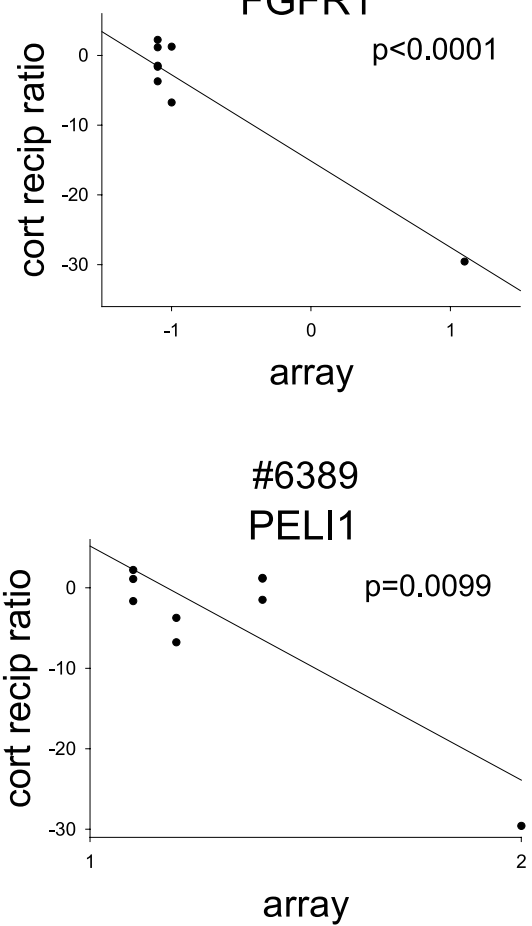

\#1578

NDUFA6

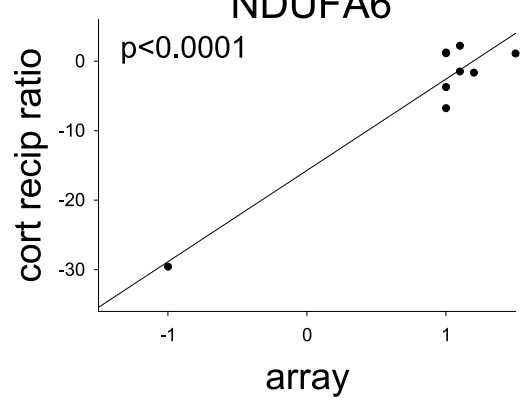

\#7356

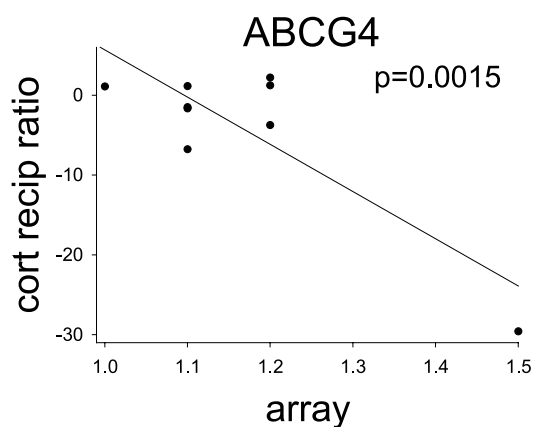

\#1851

NFE2

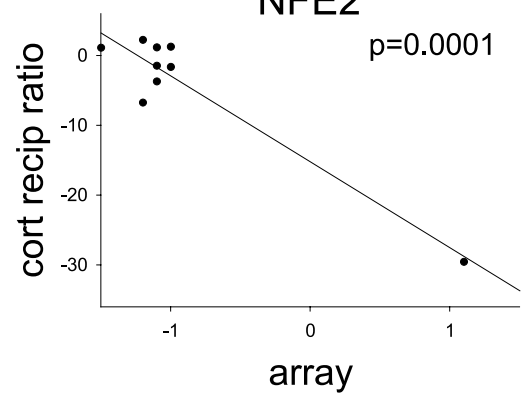

\#566

PNCK

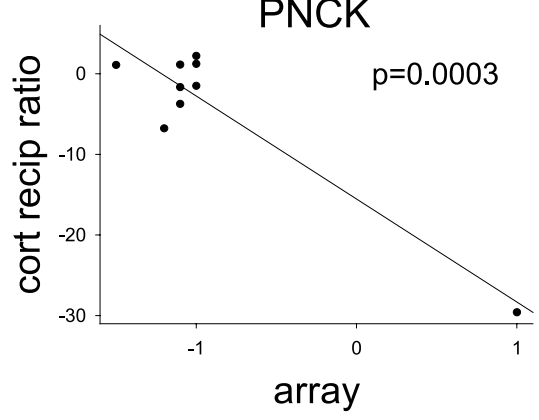

Figure 3 Representative genes showing significant correlation between microarray ratios and serum corticosterone reciprocal ratios, for category 2 genes with one or more gene pairs showing an array ratio of \pm 1.5 or greater. The correlation for category 2 genes was not significant when the lower extreme value was omitted. 

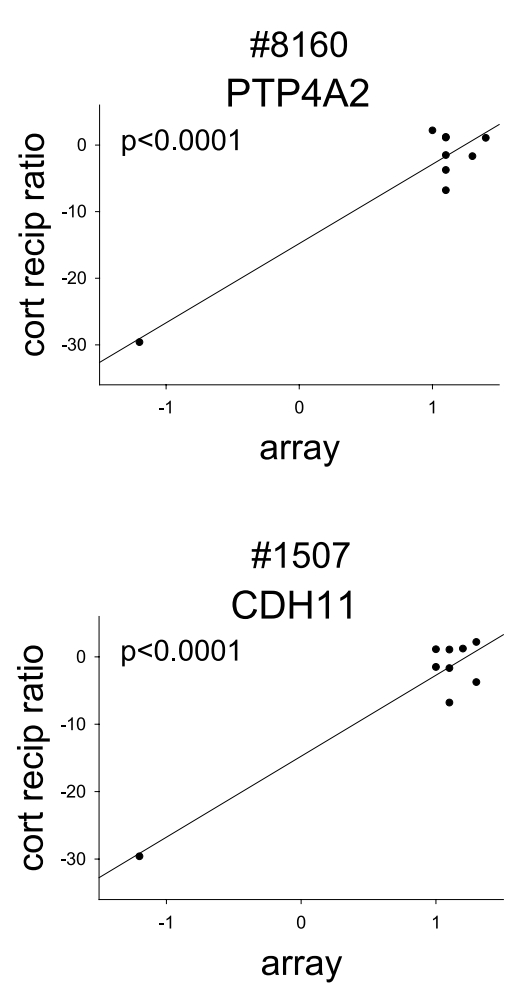

\#7835
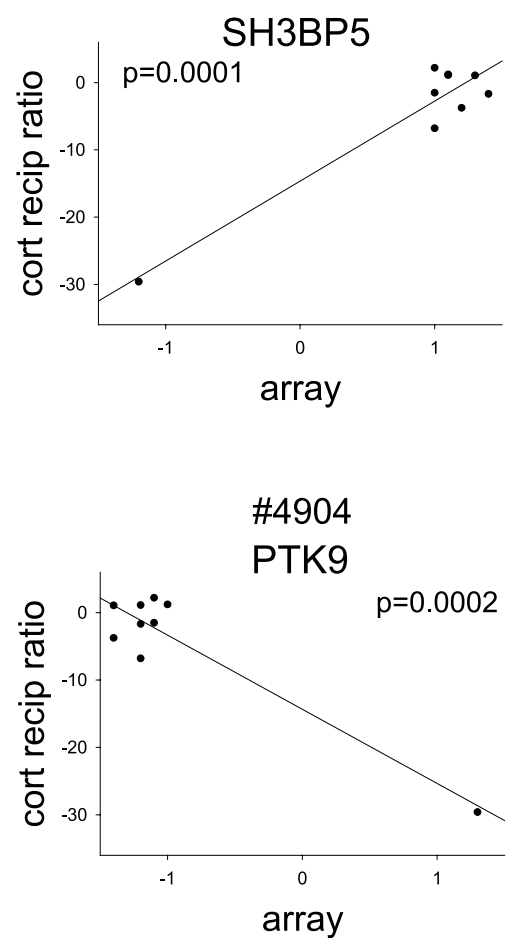
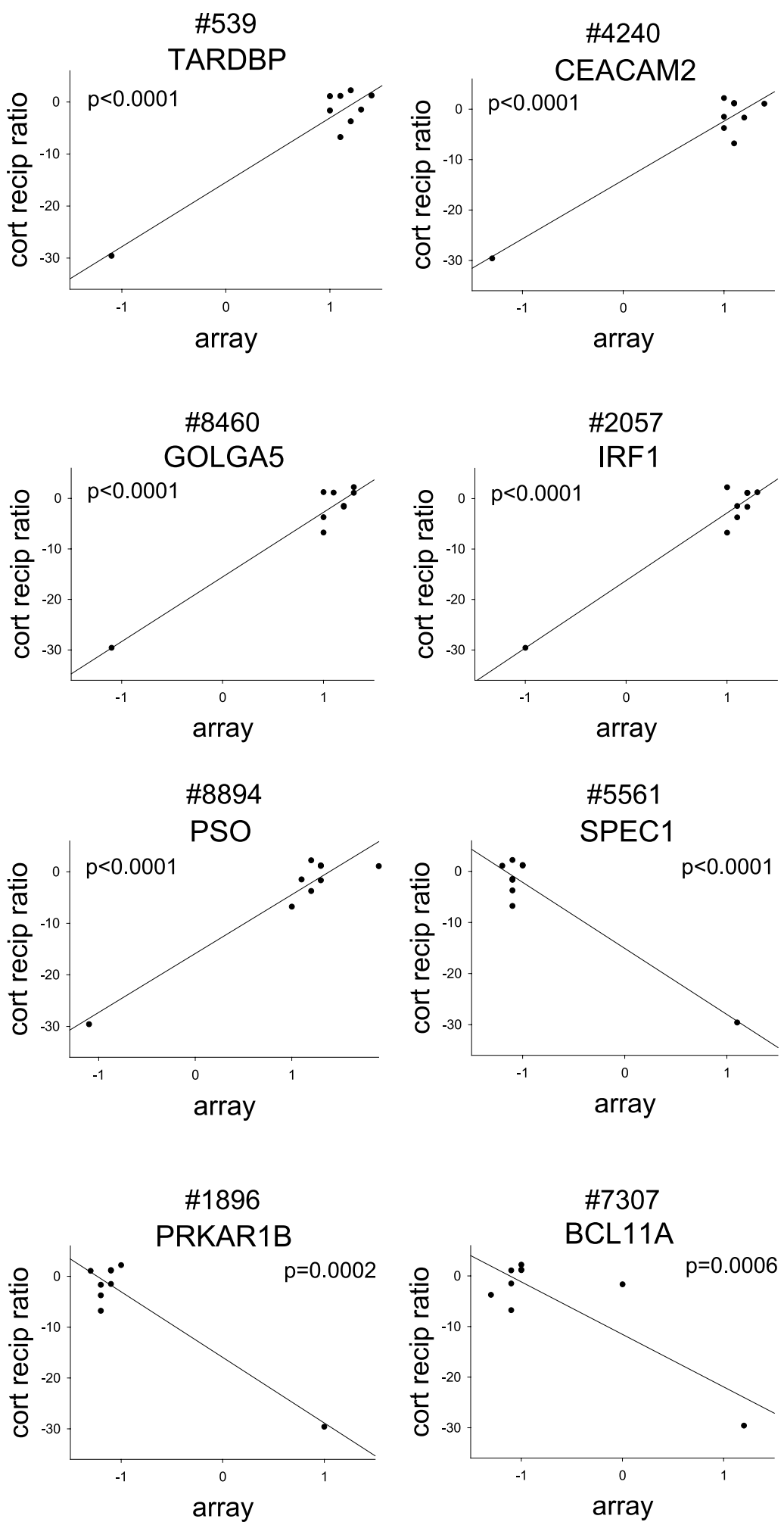

Figure 4 Representative genes showing significant correlation between microarray ratios and serum corticosterone reciprocal ratios, for category 2 genes with no gene pairs showing an array ratio of \pm 1.5 or greater. The correlation for category 2 genes was not significant when the lower extreme value was omitted. 

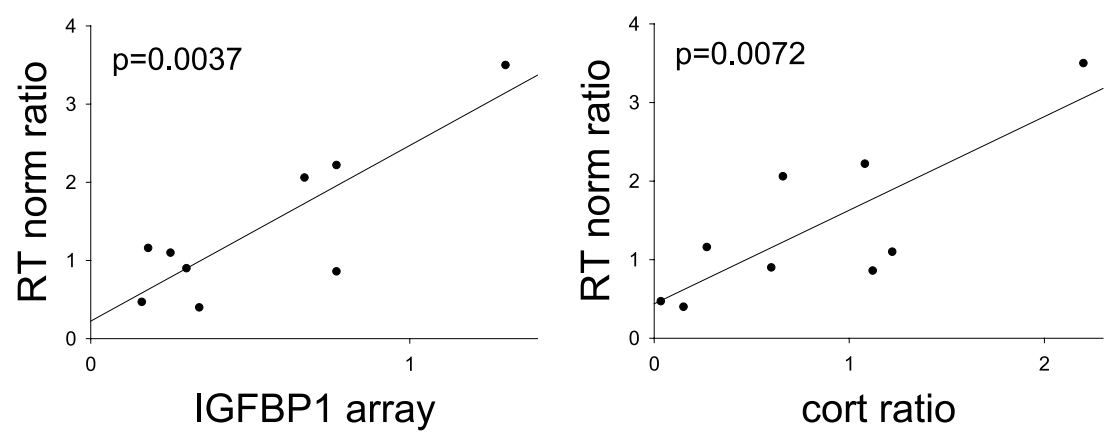

Figure 5 Confirmation of the Igfbp 1 microarray results by RT-PCR. The normalized RT ratio correlated well with the microarray ratios (left panel) and with the corticosterone ratios (right panel).
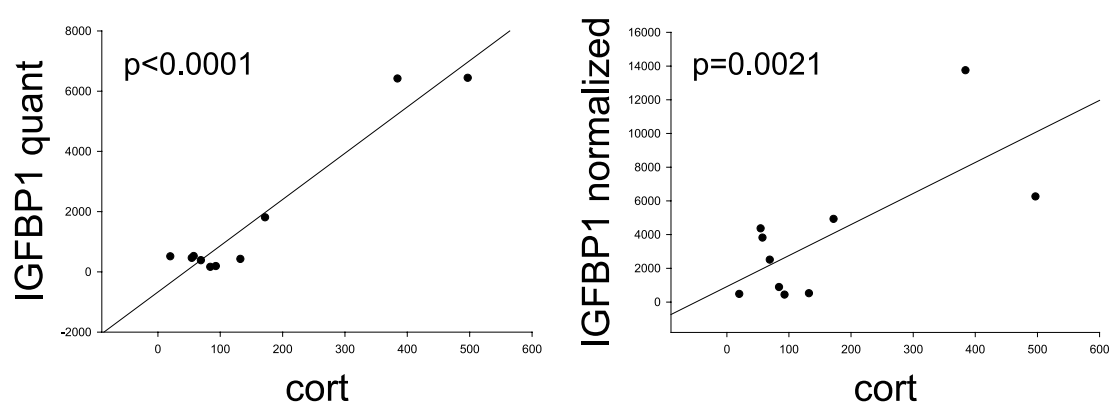

Figure 6 Confirmation of the correlation between Igfbp1 expression in liver and serum corticosterone, in a separate set of control livers, using real-time PCR, with raw Igfbp1 values (left panel) and Igfbp1 values normalized to Gapdh expression (right panel).

\section{Confirmation of correlation of hepatic Igfbp1 expression with serum corticosterone levels}

In order to confirm the striking correlation between gene expression ratios for Igfbpl in liver with corticosterone ratios in serum, $I g f b p 1$ mRNA levels were determined by semi-quantitative RT-PGR in the 18 liver samples. The ratios of these results correlated well with both microarray results (Fig. 5, left panel) and with serum corticosterone ratios (Fig. 5, right panel).

In addition, to confirm the result with $I g f b p 1$ further, livers and sera were analyzed from ten female mice of the same strain, but obtained at a different time. For this experiment, Igfbpl message was quantified by real-time PCR. As illustrated in Fig. 6 (left panel), absolute levels of $I g f b p 1$ message in liver correlated very strongly with serum corticosterone. Significant correlation was also observed when the values were normalized to Gapdh, though the scatter was greater (Fig. 6, right panel).

\section{Discussion}

The results of this investigation reveal several novel applications of microarray technology. The first is the discovery of genes showing marked, significant variation in expression in the livers of identically handled mice. There were 30 such genes, as listed in Table 2. Six of these, including four known genes, correlated with serum corticosterone ratios for the same animals. Igfbpl is known to be regulated by glucocorticoids (Lee et al. 1997, Wetterau et al. 1999), and tyrosine aminotransferase is so strongly glucocorticoid-responsive in liver that it is often used as a marker for the effects of these hormones (Granner \& Hargrove 1983, Ramakrishnan et al. 2002). The stress-induced protein gene might be expected to be regulated by corticosterone, a stress hormone. Pleiotropic regulator 1 is a part of nuclear spliceosomes (Ajuh et al. 2001) and in Arabidopsis exercises pleiotropic control of glucose and steroid hormone responses (Nemeth 
et al. 1998, Salchert et al. 1998); its regulation by glucocorticoids in mammals may not have been described.

A total of 23 genes, including 16 known genes, had significantly variable expression among the liver pairs for reasons not clearly related to serum corticosterone. Many of these code for enzymes involved in intermediary metabolism/catabolism. There were several others of possible interest in the context of individual variation in disease susceptibility. Lipin codes for a nuclear protein that plays a key role in nutrient sensing and adipocyte development (Peterfy et al. 2001, Huffman et al. 2002). Presenilin 2 contributes to Alzheimer's disease risk, and has been implicated in the processing of amyloid precursors (Edbauer et al. 2002), control of apoptosis (Alves da Costa et al. 2002), and protein synthesis (Gamliel et al. 2002). Although presenilin is expressed in liver (Benkovic et al. 1997), its function there has not been studied. The protein product of Clic4, a mitochondrial chloride channel protein, has been implicated in apoptotic response to DNA damage (FernandezSalas et al. 2002). The water channel protein aquaporin 2 apparently is not expressed in rat liver (Umenishi et al. 1996, Huebert et al. 2002), but has not been studied in mice; it may have a role in glucose-driven water transport in liver (Masyuk et al. 2002).

The reasons for the variability in the expression of these genes among this homogeneous group of mice will require more study. The contribution of genetics cannot be ruled out, since NIH Swiss mice are not inbred. However, inter-individual variation in physiological and biochemical hepatic parameters is commonly observed even among inbred animals. A practical conclusion from this aspect of the study is that the common practice of pooling two or three livers to obtain a common reference control sample for microarray studies could lead to erroneous conclusions for some genes.

The second new use for microarray was the survey of the $\sim 8000$ genes for correlation between hepatic gene expression and serum corticosterone. Corticosterone regulation of gene expression has long been known and studied in cells, animals, and humans, often with molecular constructs and/or extreme variations in concentration. Our results show that it is possible to survey comprehensively changes in tissue gene expression as related to normal variations in serum corticosterone in untreated animals. Of particular interest here was the finding that, in most of the significant correlations, the majority of the microarray values did not exceed $\pm 1 \cdot 5$. Indeed, a total of 75 correlations, listed in Tables 3 and 4, had no microarray ratio values greater than $\pm 1 \cdot 5$. Some of these correlations were very highly significant, and involved genes known to be regulated by corticosterone (see above). Heretofore, microarray ratios of $< \pm 1.5$ have been regarded as noise by most investigators. Our results suggest that these small changes are in fact meaningful. A recent study of the familial adenomatous polyposis gene revealed that a $50 \%$ reduction in expression at the RNA level was sufficient to lead to development of polyposis (Yan et al. 2002).

As noted above, many of the genes showing significant correlation with serum corticosterone in this study are already known to be glucocorticoid responsive, or at least from gene families with this characteristic. These results collectively confirm the validity of the experimental approach, and point to these genes as ones that are responsive to normal physiological variations in serum corticosterone. The other genes that correlated significantly with serum corticosterone ratios could be directly or indirectly associated. Many of these gene products are involved in metabolism and a relationship with corticosterone levels is not surprising. Also of interest are the numerous genes involved in cell growth control, that may have been revealed as glucocorticoid related for the first time. These are summarized in Table 6. In all, significant correlations with serum corticosterone were found for four growth factor/receptor genes, 18 genes for extracellular, membrane and/or signaling proteins, 16 genes for products involved in transcription or gene expression control, and five genes related to cell cycle, DNA repair, or apoptosis.

The gene whose expression correlated most strikingly with serum corticosterone was Igfbpl. This gene is well known to be inducible through glucocorticoid response elements in the promoter in both human and rat liver cells (Suh et al. 1994, 1995, 1996, Goswami et al. 1994). It is reasonable to conclude that the $I g f b p 1$ genes in the livers in our study were directly controlled by serum corticosterone, over a wide range of titers. However, insulin strongly suppresses Igfbp1 expression through a response element that interacts with the glucocorticoid control sequences (Robertson et al. 1994, 
Table 6 Summary of hepatic cell/growth control genes correlating with serum corticosterone

\begin{tabular}{|c|c|c|c|}
\hline \multirow{3}{*}{ Functional category } & \multicolumn{2}{|c|}{$\begin{array}{l}\text { Gene and direction of } \\
\text { correlation with serum } \\
\text { corticosterone }\end{array}$} & \multirow[t]{2}{*}{$\begin{array}{l}\text { References for known } \\
\text { association with } \\
\text { glucocorticoids }\end{array}$} \\
\hline & & & \\
\hline & $\operatorname{lgfbp} 1$ & $\uparrow$ & Wetterau et al. (1999) \\
\hline & Fgfr1 & $\downarrow$ & Lee et al. (1997) \\
\hline & Epha3 & $\downarrow$ & $n / \mathrm{f}$ \\
\hline & Il15ra & $\uparrow$ & $n / f$ \\
\hline \multirow[t]{17}{*}{ Extracellular/membrane/signaling } & Cdh11 & $\uparrow$ & Foty et al. (1998) \\
\hline & Prkar1b & $\downarrow$ & Dwivedi \& Pandey (2000) \\
\hline & Ihpk1 & $\uparrow$ & $\mathrm{n} / \mathrm{f}$ \\
\hline & Stk11 & $\uparrow$ & $n / f$ \\
\hline & Tmem4 & $\uparrow$ & $n / f$ \\
\hline & Pitpnb & $\uparrow$ & $n / f$ \\
\hline & Lasp1 & $\uparrow$ & $n / f$ \\
\hline & Sbk & $\uparrow$ & $n / f$ \\
\hline & Peli1 & $\downarrow$ & $n / f$ \\
\hline & Inpp5b & $\uparrow$ & $n / f$ \\
\hline & Pnck & $\downarrow$ & $n / f$ \\
\hline & Ceacam2 & $\uparrow$ & $n / f$ \\
\hline & Ptk9 & $\downarrow$ & $n / f$ \\
\hline & Spec1 & $\downarrow$ & $n / f$ \\
\hline & Sh3bp5 & $\uparrow$ & $n / f$ \\
\hline & Ptp4a2 & $\uparrow$ & $n / f$ \\
\hline & Adam9 & $\uparrow$ & $n / f$ \\
\hline \multirow[t]{16}{*}{ Transcription/gene expression } & Hnrpa2b1 & $\uparrow$ & Eggert et al. (2001) \\
\hline & Nfatc2 & $\uparrow$ & Refojo et al. (2001) \\
\hline & Myb & $\downarrow$ & Eastman-Reks \& Vedeckis (1986) \\
\hline & Irf1 & $\uparrow$ & Franchimont et al. (2000) \\
\hline & PIrg1 & $\downarrow$ & Ajah et al. (2001), Salchert et al. (1998), \\
\hline & Zfp103 & $\uparrow$ & $\mathrm{n} / \mathrm{f}$ \\
\hline & Eif3 & $\uparrow$ & $n / f$ \\
\hline & Wbscr14 & $\uparrow$ & $n / f$ \\
\hline & Crad-L & $\uparrow$ & $n / f$ \\
\hline & Sec14I2 & $\uparrow$ & $n / f$ \\
\hline & Clk2 & $\uparrow$ & $n / f$ \\
\hline & Ubn1 & $\uparrow$ & $n / f$ \\
\hline & Trim24 & $\uparrow$ & $\mathrm{n} / \mathrm{f}$ \\
\hline & $\mathrm{Nfe} 2$ & $\uparrow$ & $n / f$ \\
\hline & Tardbp & $\uparrow$ & $n / f$ \\
\hline & Bcl11a & $\downarrow$ & $\mathrm{n} / \mathrm{f}$ \\
\hline \multirow[t]{6}{*}{ Cell cycle/DNA repair/apoptosis } & Pes1 & $\uparrow$ & $n / f$ \\
\hline & Tsnax & $\uparrow$ & $n / f$ \\
\hline & Btbd1 & $\uparrow$ & $n / f$ \\
\hline & Pard3 & $\downarrow$ & $n / f$ \\
\hline & Pdcd8 & $\uparrow$ & $\mathrm{n} / \mathrm{f}$ \\
\hline & Cbpin & $\downarrow$ & $n / f$ \\
\hline
\end{tabular}

The known genes represented by the cDNAs in Tables 4 and 5 were searched using MedLine and LocusLink NCBI databases, for functions and for published reports indicating regulation by, or other relationship with, glucocorticoids. Genes with a likely relationship to cell growth control are listed.

$\mathrm{n} / \mathrm{f}$, no references found.

Suwanichkul et al. 1994), and can override the inductive effects of glucocorticoids. It has become generally accepted that insulin is the major regulator of $\operatorname{Igfbp1}$ expression, with glucocorticoids and other factors playing modulatory roles (Lee et al. 1993). Our results may be somewhat 
surprising, therefore, in suggesting that corticosterone had a predominate role in the regulation of Igfbpl expression. The suppressive effect of insulin has a concentration threshhold (Lee et al. 1993) and under conditions of hypoinsulinemia in humans cortisol causes significant increase in plasma IGFBP-1 (Conover et al. 1993). Our mice were killed in the morning, when diurnal and mealrelated levels of insulin are expected to be low (Gagliardino \& Hernandez 1971, Petersen 1978). Under these circumstances, corticosterone may provide the main control of Igfbpl expression. IGFBP-1 is known to be upregulated by fasting, exercise, and various forms of stress (Lee et al. 1993), all situations involving marked elevations in serum corticosteroids.

It is clear that regulation of $I g f b p 1$ is complex and involves numerous signaling pathways and transcription factors (Neau et al. 1995, Suh et al. 1995, Lewitt et al. 1996). Nevertheless, it may be that glucocorticoids often play a more primary role in the regulation of $I g f b p 1$ expression than hitherto suspected, and in this way may influence cancer risk. Circulating levels of IGFBP-1 regulate the bioavailability of IGF-I and IGF-II, which can be growth factors for neoplastic cells; this axis is under study as a target for cancer prevention and treatment efforts (McCarty 1997, Kari et al. 1999, Yee 2002). In addition, direct effects of IGFBP-1 on tumors have been reported (Perks et al. 1999, Zhang \& Yee 2002).

\section{References}

Ajuh P, Sleeman J, Chusainow J \& Lamond AI 2001 A direct interaction between the carboxyl-terminal region of CDC5 L and the WD40 domain of PLRG1 is essential for pre-mRNA splicing. Fournal of Biological Chemistry 276 42370-42381.

Alves da Costa C, Paitel E, Mattson MP, Amson R, Telerman A, Ancolio K, Checler F \& Mattson MP 2002 Wild-type and mutated presenilins 2 trigger p53-dependent apoptosis and down-regulate presenilin 1 expression in HEK293 human cells and in murine neurons. PNAS $994043-4048$.

Benkovic SA, McGowan EM, Rothwell NJ, Hutton M, Morgan DG \& Gordon MN 1997 Regional and cellular localization of presenilin-2 RNA in rat and human brain. Experimental Neurology $145555-564$.

Chen Y, Dougherty ER \& Bittner ML 1997 Ratio-based decision and the quantitative analysis of cDNA microarray images. Fournal of Biomedical Optics $22364-2374$.

Conover CA, Divertie GD \& Lee PDK 1993 Cortisol increases plasma insulin-like growth factor binding protein-1 in humans. Acta Endocrinologica 128 140-143.

Dwivedi Y \& Pandey GN 2000 Adrenal glucocorticoids modulate ${ }^{3} \mathrm{H}$-cyclic AMP binding to protein kinase A, cyclic AMP-dependent PKA activity, and protein levels of selective regulatory and catalytic subunit isoforms of PKA in rat brain. Journal of Pharmacology and Experimental Therapeutics 294 103-116.

Eastman-Reks SB \& Vedeckis WV 1986 Glucocorticoid inhibition of c-myc, c-myb, and c-Ki-ras expression in a mouse lymphoma cell line. Cancer Research 46 2457-2462.

Edbauer D, Winkler E, Haass C \& Steiner H 2002 Presenilin and nicastrin regulate each other and determine amyloid beta-peptide production via complex formation. PNAS 99 8666-8671.

Edenberg HJ 2000 Regulation of the mammalian alcohol dehydrogenase genes. Progress in Nucleic Acid Research and Molecular Biology 64 295-341.

Eggert H, Schulz M, Fackelmayer FO, Renkawitz R \& Eggert M 2001 Effects of the heterogeneous nuclear ribonucleoprotein $\mathrm{U}$ (hnRNP U/SAF-A) on glucocorticoid-dependent transcription in vivo. Fournal of Steroid Biochemistry and Molecular Biology 78 59-65.

Falkner KC, Pinaire JA, Xiao GH, Geoghegan TE \& Prough RA 2001 Regulation of the rat glutathione S-transferase A2 gene by glucocorticoids: involvement of both the glucocorticoid and pregnane X receptors. Molecular Pharmacology $60611-619$.

Fernandez-Salas E, Suh KS, Speransky VV, Bowers WL, Levy JM, Adams T, Patak KR, Edwards LE, Hayes DD, Cheng C, Steven AC, Weinberg WC \& Yuspa SH 2002 mtCLIC/CLIC4, an organellular chloride channel protein, is increased by DNA damage and participates in the apoptotic response to p53. Molecular Cell Biology 22 3610-3620.

Foty RA, Corbett SA, Schwarzbauer JE \& Steinberg MS 1998 Dexamethasone up-regulates cadherin expression and cohesion of HT-1080 human fibrosarcoma cells. Cancer Research $\mathbf{5 8}$ 3586-3589.

Franchimont D, Galon JJ, Gadina M, Visconti R, Zhou Y, Aringer M, Frucht DM, Chrousos GP \& O'Shea IJ 2000 Inhibition of Thl immune response by glucocorticoids: dexamethasone selectively inhibits IL-12-induced Stat 4 phosphorylation in T lymphocytes. Fournal of Immunology 164 1768-1774.

Gagliardino JJ \& Hernandez RE 1971 Circadian variation of the serum glucose and immunoreactive insulin levels. Endocrinology $\mathbf{8 8}$ $1532-1534$.

Galman C, Angelin B \& Rudling M 2002 Prolonged stimulation of the adrenals by corticotropin suppresses hepatic low-density lipoprotein and high-density lipoprotein receptors and increases plasma cholesterol. Endocrinology 143 1809-1816.

Gamliel A, Teicher C, Michaelson DM, Pradier L, Hartmann T, Beyreuther K \& Stein R 2002 Increased expression of presenilin 2 inhibits protein synthesis. Molecular and Cellular Neuroscience 19 $111-124$

Goswami R, Lacson R, Yang E, Sam R \& Unterman T 1994 Functional analysis of glucocorticoid and insulin response sequences in the rat insulin-like growth factor-binding protein-1 promoter. Endocrinology 134 736-743.

Granner DK \& Hargrove JL 1983 Regulation of the synthesis of tyrosine aminotransferase: the relationship to mRNA TAT. Molecular Cell Biology 53 113-128.

Huebert RC, Splinter PL, Garcia F, Marinelli RA \& LaRusso NF 2002 Expression and localization of aquaporin water channels in rat hepatocytes. Evidence for a role in canalicular bile secretion. fournal of Biological Chemistry 277 22710-22717.

Huffman TA, Mothe-Satney I \& Lawrence JC 2002 Insulinstimulated phosphorylation of lipin mediated by the mammalian target of rapamycin. PNAS 99 1047-1052.

Kalamidas SA \& Kotoulas OB 2000 Studies on the breakdown of glycogen in the lysosomes: the effects of hydrocortisone. Histology and Histopathology 15 29-35.

Kari FW, Dunn SE, French JE \& Barrett JC 1999 Roles for insulin-like growth factor-1 in mediating the anti-carcinogenic effects of calorie restriction. Fournal of Nutrition, Health and Aging $\mathbf{3}$ 92-101. 
Kowaloff EM, Granger ES \& Phang JM 1977 Glucocorticoid control of hepatic proline oxidase. Metabolism 26 893-901.

Lee PDK, Conover CA \& Powell DR 1993 Regulation and function of insulin-like growth factor-binding protein-1. Proceedings of the Society for Experimental Biology and Medicine 204 4-29.

Lee PDK, Giudice LC, Conover CA \& Powell DR 1997 Insulin-like growth factor binding protein-1: recent findings and new directions. Proceedings of the Society for Experimental Biology and Medicine 216 319-357.

Lewitt MS, Saunders H \& Baxter RC 1996 Interaction of insulin, glucocorticoids, and protein kinase $\mathrm{C}$ in the regulation of insulin-like growth factor-binding protein-1 production by $\mathrm{H} 4 \mathrm{IIE}$ rat hepatoma cells. Fournal of Cell Physiology 166 121-129.

McCarty MF 1997 Up-regulation of IGF binding protein-1 as an anticarcinogenic strategy: relevance to caloric restriction, exercise and insulin sensitivity. Medical Hypotheses 48 297-308.

Malerod L, Juvet K, Gjoen T \& Berg T 2002 The expression of scavenger receptor $\mathrm{B}$, type I (SR-BI) and caveolin- 1 in parenchymal and nonparenchymal liver cells. Cell and Tissue Research 307 173-180.

Masyuk AI, Masyuk TV, Teitz PS, Splinter PL \& LaRusso NF 2002 Intrahepatic bile ducts transport water in response to absorbed glucose. American Fournal of Physiology and Cell Physiology 283 C785-C791.

Neau E, Chambery D, Schweizer-Groyer G, Cadepond F, Jibard N \& Groyer A 1995 Multiple liver-enriched trans-acting factors interact with the glucocorticoid- and cAMP-responsive units within the h-IGFBP-1 promoter. Progress in Growth Factor Research 6 103-117.

Nemeth K, Salchert K, Putnoky P, Bhalerao R, Koncz-Kalman Z, Stankovic-Stangeland B, Bako L, Mathur J, Okresz L, Stabel S, Geigenberger P, Stitt M, Redei GP, Schell J \& Koncz C 1998 Pleiotropic control of glucose and hormone responses by PRL1, a nuclear WD protein, in Arabidopsis. Genes and Development 12 3059-3073.

Perks CM, Newcomb PV, Norma MR \& Holly JM 1999 Effect of insulin-like growth factor binding protein-1 on integrin signalling and the induction of apoptosis in human breast cancer cells. Fournal of Molecular Endocrinology 22 141-150.

Peterfy M, Phan J, Xu P \& Reue K 2001 Lipodystrophy in the fld mouse results from mutation of a new gene encoding a nuclear protein, lipin. Nature Genetics 27 121-124.

Petersen S 1978 Feeding, blood glucose and plasma insulin of mice at dusk. Nature 275 647-649.

Powell DA, Anderson LM, Cheng RYS \& Alvord WG 2002 The robustness of the Chen-Dougherty-Bittner procedure against nonnormality and heterogeneity in the coefficient of variation. Fournal of Biomedical Optics 7 650-660.

Ramakrishnan R, DuBois DC, Almon RR, Pyszczynski NA \& Jusko WJ 2002 Pharmacodynamics and pharmacogenomics of methylprednisolone during 7-day infusions in rats. Fournal of Pharmacology and Experimental Therapeutics 300 245-256.
Refojo D, Liberman AC, Holsboer F \& Arzt E 2001 Transcription factor-mediated molecular mechanisms involved in the functional cross-talk between cytokines and glucocorticoids. Immunology and Cell Biology 79 385-394.

Riva MA, Molteni R \& Racagni G 1998 Differential regulation of FGF-2 and FGFR-1 in rat cortical astrocytes by dexamethasone and isoproterenol. Brain Research and Molecular Brain Research 57 38- 45.

Robertson DG, Marino EM, Thule PM, Seneviratne CK \& Murphy LJ 1994 Insulin and glucocorticoids regulate IGFBP-1 expression via a common promoter region. Biochemical and Biophysical Research Communications 200 226-232.

Salchert K, Bhalerao R, Koncz-Kalman Z \& Koncz C 1998 Control of cell elongation and stress responses by steroid hormones and carbon catabolic repression in plants. Philosophical Transactions of the Royal Society of London, B, Biological Sciences 353 1517-1520.

Suh DS, Ooi GT \& Rechler MM 1994 Identification of the Cis-elements mediating the stimulation of rat insulin-like growth factor-binding protein-1 promoter activity by dexamethasone, cyclic adenosine $3^{\prime}, 5^{\prime}$-monophosphate, and phorbol esters, and inhibition by insulin. Molecular Endocrinology 8 794-805.

Suh DS, Zhou Y, Ooi GT \& Rechler MM 1995 Dexamethasone stimulation of rat insulin-like growth factor binding protein-1 promoter activity involves the interaction of multiple transcription factors. Progress in Growth Factor Research 6 131-140.

Suh DS, Zhou Y, Ooi GT \& Rechler MM 1996 Dexamethasone stimulation of rat insulin-like growth factor binding protein-1 promoter activity involves multiple cis-elements. Molecular Endocrinology 10 1227-1237.

Suwanichkul A, Allander SV, Morris SL \& Powell DR 1994 Glucocorticoids and insulin regulate expression of the human gene for insulin-like growth factor-binding protein-1 through proximal promoter elements. Fournal of Biological Chemistry 269 30835-30841.

Umenishi F, Verkman AS \& Gropper MA 1996 Quantitative analysis of aquaporin mRNA expression in rat tissues by RNase protection assay. DNA and Cell Biology 15 475-580.

Wetterau LA, Moore MG, Lee KW, Shim ML \& Cohen P 1999 Novel aspects of the insulin-like growth factor binding proteins. Molecular Genetics and Metabolism 68 161-181.

Yan H, Dobbie Z, Gruber SB, Markowitz S, Romans K, Giardiello FM, Kinzler KW \& Vogelstein B 2002 Small changes in expression affect predisposition to tumorigenesis. Nature Genetics $3025-26$.

Yee D 2002 The insulin-like growth factor system as a treatment target in breast cancer. Seminars in Oncology 29 (Suppl 11) 86-95.

Zhang X \& Yee D 2002 Insulin-like growth factor binding protein 1(IGFBP-1) inhibits breast cancer cell motility. Cancer Research 62 $4369-4375$.

Received 25 June 2003

Accepted 29 September 2003 